\title{
Putative $\beta_{4}$-adrenoceptors in rat ventricle mediate increases in contractile force and cell $\mathrm{Ca}^{2+}$ : comparison with atrial receptors and relationship to $(-)-\left[{ }^{3} \mathrm{H}\right]-\mathrm{CGP} 12177$ binding
}

\author{
${ }^{1}$ Doreen Sarsero, ${ }^{*, 1,2}$ Peter Molenaar, ${ }^{3,4}$ Alberto J. Kaumann \& ${ }^{3,5}$ Nicholas S. Freestone \\ ${ }^{1}$ Department of Pharmacology, University of Melbourne, Parkville, 3052, Victoria, Australia; ${ }^{2}$ Cardiovascular Research Unit, \\ Department of Medicine, University of Queensland, Prince Charles Hospital, Chermside, 4032, Queensland, Australia; ${ }^{3}$ Laboratory \\ of Molecular Signalling, The Babraham Institute, Cambridge, CB2 4AT and ${ }^{4}$ Physiological Laboratory, University of Cambridge, \\ Cambridge, CB2 3EG.
}

1 We identified putative $\beta_{4}$-adrenoceptors by radioligand binding, measured increases in ventricular contractile force by (-)-CGP 12177 and ( \pm )-cyanopindolol and demonstrated increased $\mathrm{Ca}^{2+}$ transients by $(-)$-CGP 12177 in rat cardiomyocytes.

2 (-)-[3 $\mathrm{H}]$-CGP 12177 labelled $13-22 \mathrm{fmol} \mathrm{mg}^{-1}$ protein ventricular $\beta_{1}, \beta_{2}$-adrenoceptors $\left(\mathrm{pK} \mathrm{D}_{\mathrm{D}}\right.$

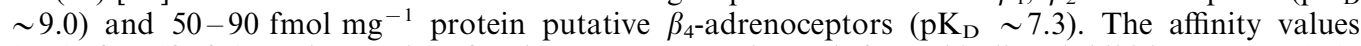
$\left(\mathrm{pK}_{\mathrm{i}}\right)$ for $\left(\beta_{1}, \beta_{2^{-}}\right)$and putative $\beta_{4}$-adrenoceptors, estimated from binding inhibition, were $(-)$ propranolol 8.4, 5.7; (-)-bupranolol 9.7, 5.8; (土)-cyanopindolol 10.0,7.4.

3 In left ventricular papillary muscle, in the presence of $30 \mu \mathrm{M} 3$-isobutyl-1-methylxanthine, (-)CGP 12177 and $( \pm)$-cyanopindolol caused positive inotropic effects, $\left(\mathrm{pEC}_{50},(-)\right.$-CGP 12177, 7.6; ( \pm )-cyanopindolol, 7.0) which were antagonized by (-)-bupranolol $\left(\mathrm{pK}_{\mathrm{B}}\right.$ 6.7-7.0) and (-)-CGP $20712 \mathrm{~A}\left(\mathrm{pK}_{\mathrm{B}} 6.3-6.6\right)$. The cardiostimulant effects of (-)-CGP 12177 in papillary muscle, left and right atrium were antagonized by $( \pm)$-cyanopindolol $\left(\mathrm{pK}_{\mathrm{P}} 7.0-7.4\right)$.

4 (-)-CGP $12177(1 \mu \mathrm{M})$ in the presence of $200 \mathrm{nM}(-)$-propranolol increased $\mathrm{Ca}^{2+}$ transient amplitude by $56 \%$ in atrial myocytes, but only caused a marginal increase in ventricular myocytes. In the presence of $1 \mu \mathrm{M}$ 3-isobutyl-1-methylxanthine and $200 \mathrm{nM}(-)$-propranolol, $1 \mu \mathrm{M}(-)$-CGP 12177 caused a $73 \%$ increase in $\mathrm{Ca}^{2+}$ transient amplitude in ventricular myocytes. (-)-CGP 12177 elicited arrhythmic transients in some atrial and ventricular myocytes.

5 Probably by preventing cyclic AMP hydrolysis, 3-isobutyl-1-methylxanthine facilitates the inotropic function of ventricular putative $\beta_{4}$-adrenoceptors, suggesting coupling to $G_{\mathrm{s}}$ proteinadenylyl cyclase. The receptor-mediated increases in contractile force are related to increases of $\mathrm{Ca}^{2+}$ in atrial and ventricular myocytes. The agreement of binding affinities of agonists with cardiostimulant potencies is consistent with mediation through putative $\beta_{4}$-adrenoceptors labelled with $(-)-\left[{ }^{3} \mathrm{H}\right]-\mathrm{CGP} 12177$.

Keywords: Putative $\beta_{4}$-adrenoceptor; (-)-CGP 12177; (-)-[ $\left[{ }^{3} \mathrm{H}\right]$-CGP 12177; ( \pm )-cyanopindolol; contractile force; Ca ${ }^{2+}$ transient; rat cardiomyocytes; rat ventricle; rat atrium

Abbreviations: BRL 37344, (RR + SS)[4-[2-[[2-(3-chlorophenyl)-2-hydroxy-ethyl]amino]propyl]phenoxy]acetic acid; (-)-CGP 12177, (-)-4-(3-tertiarybutylamino-2-hydroxypropoxy) benzimidazol-2-one; CGP 20712A, 2-hydroxy-5(2-((2hydroxy-3-(4-((1-methyl-4-trifluoromethyl) 1H-imidazole-2-yl) -phenoxy) propyl) amino) ethoxy)-benzamide monomethane sulphonate; GTP, guanosine 5-triphosphate; IBMX, 3-isobutyl-1-methylxanthine; ICI 118,551 (erythro-DL-1(7-methylindan-4-yloxy)-3-isopropylamino-butan-2-ol)

\section{Introduction}

Evidence is accumulating from functional, second messenger and radioligand binding studies for the existence of a putative $\beta_{4}$-adrenoceptor in rat atrium which is pharmacologically distinct from $\beta_{1^{-}}, \beta_{2^{-}}$and $\beta_{3}$-adrenoceptors. In rat atrium, the putative $\beta_{4}$-adrenoceptor is stimulated in vivo (Malinowska \& Schlicker, 1996) and in vitro (Kaumann \& Molenaar, 1996; Kaumann \& Lynham, 1997) by non-conventional partial agonists (Kaumann, 1989) such as (-)-CGP 12177 and ( \pm )cyanopindolol, compounds which are high affinity antagonists at $\beta_{1}$ - and $\beta_{2}$-adrenoceptors but cause cardiostimulant effects at considerably higher concentrations than those required to block $\beta_{1}$ - and $\beta_{2}$-adrenoceptors. The cardiostimulant effects of

\footnotetext{
*Author for correspondence at: Department of Medicine, University of Queensland, Prince Charles Hospital, Chermside, 4032, Queensland, Australia. E-mail: molenaar@medicine.uq.edu.au ${ }^{5}$ Current address: Laboratory for Clinical and Experimental Heart Failure, Franz-Vollard Clinic, Berlin, 13125, Germany
}

(-)-CGP 12177 in rat right and left atrium were shown to be potentiated by the phosphodiesterase inhibitor IBMX (Kaumann \& Lynham, 1997) and were associated with increases in cyclic AMP (Kaumann et al., 1997) and cyclic AMPdependent protein kinase (PKA) activity (Kaumann \& Lynham, 1997), providing evidence that the putative $\beta_{4^{-}}$ adrenoceptor is probably coupled to the $G_{s \alpha}$ protein-adenylyl cyclase pathway. (-)-[ $\left.{ }^{3} \mathrm{H}\right]-\mathrm{CGP} 12177$ binding has revealed a putative $\beta_{4}$-adrenoceptor population in rat atria that is larger than the combined populations of $\beta_{1}, \beta_{2}$-adrenoceptors (Sarsero et al., 1998).

We previously reported that (-)-CGP 12177 and ( \pm )cyanopindolol did not cause positive inotropic effects in rat ventricular papillary muscles (Kaumann \& Molenaar, 1996). This may be due to the absence of the putative $\beta_{4}$-adrenoceptor in ventricle, a low density of receptors or inefficient receptor- $G_{s}$ protein coupling with subsequent small generation of second messengers. We now tested these hypotheses by using a 
recently developed radioligand binding assay for the putative $\beta_{4}$-adrenoceptor (Sarsero et al., 1998) and in further functional experiments. In the light of experiments in rat atria which showed that positive inotropic effects of (-)-CGP 12177 could be potentiated by the phosphodiesterase inhibitor IBMX (Kaumann \& Lynham, 1997) we thought that inhibition of cyclic AMP hydrolysis in rat ventricle might reveal putative $\beta_{4^{-}}$ adrenoceptor-mediated positive inotropic effects. Activation of the $\mathrm{G}_{\mathrm{s}}$-adenylyl cyclase pathway by stimulation of $\beta_{1^{-}}$ adrenoceptors in rat ventricular myocytes is associated with increases in $\mathrm{Ca}^{2+}$ transients (Xiao \& Lakatta, 1993). We therefore investigated whether stimulation of atrial and ventricular putative $\beta_{4}$-adrenoceptors also caused increases in $\mathrm{Ca}^{2+}$ transients.

(-)-CGP 12177 and ( \pm )-cyanopindolol caused positive inotropic effects in rat papillary muscle in the presence of IBMX which we attribute to stimulation of the putative $\beta_{4}$ adrenoceptor. The positive inotropic effects of (-)-CGP 12177 in atrium and ventricle are associated with an enhancement of $\mathrm{Ca}^{2+}$ transients in atrial and ventricular myocytes. Radioligand binding studies with (-)-[ $\left.{ }^{3} \mathrm{H}\right]-\mathrm{CGP} 12177$ identified a higher density of ventricular putative $\beta_{4}$-adrenoceptors than $\beta_{1}, \beta_{2}$-adrenoceptors as found previously in rat atria (Sarsero et al., 1998).

Progress reports of this work were presented at the ASPET meeting, San Diego, 1997 (Freestone \& Kaumann, 1997; Kaumann \& Freestone, 1997; Sarsero et al., 1997).

\section{Methods}

Sprague-Dawley rats, either sex $(250-300 \mathrm{~g})$ were stunned by a blow on the head, exsanguinated, the heart rapidly removed and placed immediately into continuously oxygenated $(95 \%$ $\mathrm{O}_{2} / 5 \% \mathrm{CO}_{2}$ ) modified Krebs solution (mM): $\mathrm{Na}^{+} 125, \mathrm{~K}^{+} 5$, $\mathrm{Ca}^{2+} 2.25, \mathrm{Mg}^{2+} 0.5, \mathrm{Cl}^{-} 98.5, \mathrm{SO}_{4}{ }^{2-} 0.5, \mathrm{HCO}_{3}{ }^{-} 32, \mathrm{HPO}_{4}{ }^{2-}$ 1, EDTA 0.04, Gille et al. (1985) at room temperature (18$\left.22^{\circ} \mathrm{C}\right)$.

\section{Radioligand binding studies}

Membrane preparation The left ventricle including the interventricular septum was dissected free of the right ventricular free wall, cardiac valves and great vessels in continuously oxygenated modified Krebs solution (composition above), snap frozen with liquid nitrogen pre-cooled clamps and stored at $-70^{\circ} \mathrm{C}$ until use. The left ventricle was homogenized with an Ultra-Turrax homogenizer (model T25) using three $10 \mathrm{~s}$ bursts at 12,000 r.p.m. in ice-cold Tris/ $\mathrm{Mg}^{2+}$ assay buffer (composition in $\mathrm{mM}$ ): Tris- $\mathrm{HCl}, 50$; EGTA, 5; EDTA, $1 ; \mathrm{MgCl}_{2}$ 4; ascorbic acid, 1; phenylmethylsulphonyl fluoride, $0.5 ; \mathrm{pH} \mathrm{7.4}$, then centrifuged for $5 \mathrm{~min}$ at $30 \times g\left(4^{\circ} \mathrm{C}\right)$. The supernatant was centrifuged at $50,000 \times g\left(4^{\circ} \mathrm{C}\right)$ for $15 \mathrm{~min}$ and the pellet resuspended in 15 volumes ice-cold assay buffer.

Experiments were performed in assay buffer with or without GTP $(0.1 \mathrm{~mm})$ at $37^{\circ} \mathrm{C}$ for $120 \mathrm{~min}$.

Saturation experiments Binding to $\beta_{1}$ - and $\beta_{2}$-adrenoceptor binding sites was carried out with $0.01-20 \mathrm{nM}(-)-\left[{ }^{3} \mathrm{H}\right]-\mathrm{CGP}$ 12177 in the absence or presence of $500 \mathrm{nM}(-)$-propranolol to define non-specific binding. Binding to $\beta_{1^{-}}, \beta_{2^{-}}$and putative $\beta_{4^{-}}$ adrenoceptors was carried out with $0.01-200 \mathrm{nM}(-)-\left[{ }^{3} \mathrm{H}\right]-$ CGP 12177 in the absence or presence of $20 \mu \mathrm{M}(-)$-CGP 12177 to define non-specific binding. Finally, in order to determine whether it was possible to label putative $\beta_{4^{-}}$ adrenoceptors only, 1-200 nM (-)-[ $\left.{ }^{3} \mathrm{H}\right]$-CGP 12177 was used together with $500 \mathrm{nM}(-)$-propranolol to block $\beta_{1^{-}}$and $\beta_{2^{-}}$ adrenoceptors. Non-specific binding was determined with $20 \mu \mathrm{M}$ (-)-CGP 12177 (Sarsero et al., 1998). Assays were terminated by addition of $5 \mathrm{ml}$ ice-cold Tris wash buffer (Tris$\mathrm{HCl}, 50 \mathrm{~mm}, \mathrm{pH}$ 7.4) followed by rapid filtration (Brandel M$30 \mathrm{R}$ cell harvester) over GF/B filters. Radioactivity retained on filter paper was counted in a Packard beta-counter (Model TriCarb 460 CD).

Saturation binding experiments at $\beta_{1}, \beta_{2}$-adrenoceptors were analysed for one binding site by non-linear curve fitting with the equation:

$$
\begin{aligned}
& \mathrm{Beq}= \\
& \left(\mathrm{B}_{\max \beta} \cdot\left[(-)-\left[{ }^{3} \mathrm{H}\right]-\mathrm{CGP} 12177\right]\right) /\left(\mathrm{K}_{\beta}+\left[(-)-\left[{ }^{3} \mathrm{H}\right]-\mathrm{CGP} 12177\right]\right)
\end{aligned}
$$

where Beq is the amount of $(-)-\left[{ }^{3} \mathrm{H}\right]-\mathrm{CGP} 12177$ binding at equilibrium, $\mathbf{B}_{\max \beta}$ is the maximal density of $\beta_{1}, \beta_{2}$-adrenoceptors, $\mathrm{K}_{\beta}$ is the equilibrium dissociation constant $\left(\mathrm{K}_{\mathrm{D}}\right)$ of $(-)$ [ $\left.{ }^{3} \mathrm{H}\right]$-CGP 12177 at $\beta_{1}, \beta_{2}$-adrenoceptors. We assumed that $\mathrm{K}_{\beta 1} \cong \mathrm{K}_{\beta 2}$ (Nanoff et al., 1987).

Saturation binding experiments in the absence of $500 \mathrm{nM}$ (-)-propranolol were analysed for two binding sites by nonlinear curve fitting with the equation:

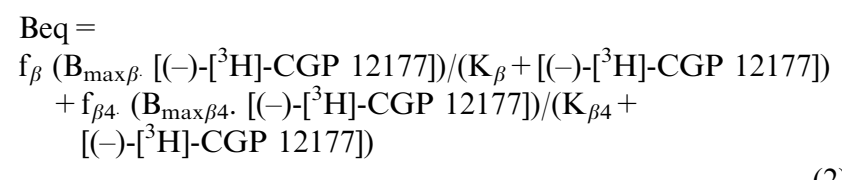

where Beq is defined as in equation (1), $\mathrm{f}_{\beta}$ and $\mathrm{f}_{\beta 4}$ are fractions of $\beta_{1}, \beta_{2^{-}}$and putative $\beta_{4}$-adrenoceptor populations respectively, $\mathrm{B}_{\max \beta}$ is the maximal density of $\beta_{1}, \beta_{2}$-adrenoceptors, $\mathrm{B}_{\max \beta 4}$ is the maximal density of putative $\beta_{4}$-adrenoceptors, $\mathrm{K}_{\beta}$ and $\mathrm{K}_{\beta 4}$ are equilibrium dissociation constants of $(-)-\left[{ }^{3} \mathrm{H}\right]-$ CGP 12177 at $\beta_{1}, \beta_{2}$-adrenoceptors and putative $\beta_{4}$-adrenoceptors respectively.

Saturation binding experiments carried out in the presence of $500 \mathrm{nM}(-)$-propranolol were analysed with the equation:

$$
\begin{aligned}
& \mathrm{Beq}= \\
& \left.\mathrm{f}_{\beta}\left(\mathrm{B}_{\max \beta} \text {. [(-)-[ }\left[{ }^{3} \mathrm{H}\right]-\mathrm{CGP} 12177\right]\right) /\left(\left[(-)-\left[{ }^{3} \mathrm{H}\right]-\mathrm{CGP} 12177\right]\right. \\
& \left.+\mathrm{K}_{\beta}\left(1+[(-) \text {-propranolol }] / \mathrm{Ki}_{(-)-\text {propranolol } \beta}\right)\right) \\
& +\mathrm{f}_{\beta 4}\left(\mathrm{~B}_{\max \beta 4}\left[(-)-\left[{ }^{3} \mathrm{H}\right]-\mathrm{CGP} 12177\right]\right) /\left(\left[(-)-\left[^{3} \mathrm{H}\right]-\mathrm{CGP} 12177\right]\right. \\
& \left.+\mathrm{K}_{\beta 4}\left(1+[(-) \text {-propranolol }] / \mathrm{Ki}_{(-)-\text {propranolol } \beta 4}\right)\right)
\end{aligned}
$$

$\mathrm{Ki}_{(-) \text {-propranolol } \beta}, \mathrm{Ki}_{(-) \text {-propranolol } \beta 4}$ are equilibrium dissociation constants of $(-)$-propranolol at $\beta_{1}, \beta_{2}$-adrenoceptors and putative $\beta_{4}$-adrenoceptors respectively. Other abbreviations as in equations (1) and (2).

Competition binding studies In competition binding experiments at $\beta_{1}, \beta_{2}$-adrenoceptors, a single concentration of (-)[ $\left.{ }^{3} \mathrm{H}\right]$-CGP 12177 (approximately $1 \mathrm{nM}$ ) was used with nonspecific binding defined with $500 \mathrm{~nm}(-)$-propranolol and were analysed using non-linear curve fitting according to the equation:

$$
\mathrm{Beq}=\mathrm{Bsb} /\left(1+10^{\left([\mathrm{competitor}]-\log \mathrm{IC}_{50}\right)}\right)
$$

where Beq is as in equations (1) and (2), Bsb=specifically bound (-)-[3H]-CGP 12177 in the absence of competitor, $\mathrm{IC}_{50}=$ the concentration of competitor causing $50 \%$ inhibition. The $\mathrm{pK}_{\mathrm{i}}$ for the competitor was then calculated from the Cheng and Prussoff equation (Cheng \& Prussoff, 1973). 
Competition binding experiments between $(-)-\left[{ }^{3} \mathrm{H}\right]-\mathrm{CGP}$ 12177 and other competitors were analysed for competition at multiple populations/states, fi $(i=1, \ldots \ldots, n)$ by the equation of the general form:

$$
\mathrm{Beq}=\sum_{\mathrm{i}} \text { fi } \quad\left(\mathrm{B}_{\max } \cdot \mathrm{L}^{*}\right) /\left\{\left(\mathrm{L}^{*}+\mathrm{K}_{\mathrm{L}^{*}}\left(1+\mathrm{L} / \mathrm{K}_{\mathrm{L}}\right)\right\}\right.
$$

where $\mathrm{B}_{\max }$ is the density of receptors, $\mathrm{L}^{*}$ and $\mathrm{L}$ are concentrations of radioligand and competing ligand respectively, $\mathrm{K}_{\mathrm{L}^{*}}$ and $\mathrm{K}_{\mathrm{L}}$ are dissociation constants of radioligand and competing ligand respectively.

For competition binding experiments between $(-)-\left[{ }^{3} \mathrm{H}\right]-$ CGP 12177 and competitors in the presence of $(-)$ propranolol the equation becomes:

$$
\begin{aligned}
& \mathrm{Beq}=\sum_{\mathrm{i}} \mathrm{fi} \quad\left(\mathrm{B}_{\max } \cdot \mathrm{L}^{*}\right) /\left\{\left(\mathrm{L}^{*}+\mathrm{K}_{\mathrm{L} 6^{*}}\left(1+\mathrm{L} / \mathrm{K}_{\mathrm{L}}\right)\right.\right. \\
& \left.+\mathrm{K}_{\mathrm{L}^{*}}\left(1+\operatorname{Prop} / \mathrm{K}_{\text {prop }}\right)\right\}
\end{aligned}
$$

where Prop is the concentration of $(-)$-propranolol and $\mathrm{K}_{\text {prop }}$ is the dissociation constant of $(-)$-propranolol for receptor population i.

Non-specific binding was determined with $20 \mu \mathrm{M}(-)$-CGP 12177. Protein was determined (Lowry et al., 1951) using bovine serum albumin as a standard. Saturation and competition binding data were analysed by non-linear regression by PRISM (GraphPad Software, Inc.).

\section{Functional studies}

Isolated atria and papillary muscles Left and right atria and one or two left ventricular papillary muscles were dissected from each heart and mounted in pairs in a $50 \mathrm{ml}$ tissue bath (Blinks, 1965) containing modified Krebs solution at $37^{\circ} \mathrm{C}$ and attached to strain-gauge transducers as described previously (Kaumann \& Molenaar, 1996). Left atria and papillary muscles were driven with square wave pulses $(2 \mathrm{~Hz}, 5 \mathrm{~ms}$ duration, just over threshold voltage). Spontaneously beating right atria were set up with just enough tension to enable contractions to be counted on a polygraph. The incubation medium was exchanged with modified Krebs solution containing in addition (mM): $\mathrm{Na}^{+} 15$, fumarate 5 , pyruvate 5 , Lglutamate 5 and glucose 10. (-)-Propranolol $200 \mathrm{nM}$ was added to the bath to block $\beta_{1}$ - and $\beta_{2}$-adrenoceptors which has previously been shown not to affect the positive inotropic effects of (-)-CGP 12177 or $( \pm)$-cyanopindolol in rat atrium (Kaumann \& Molenaar, 1996). In some experiments, $1 \mu \mathrm{M}$ (-)-bupranolol or $3 \mu \mathrm{M}$ CGP 20712A were added to the bath and allowed to equilibrate for $60 \mathrm{~min}$. For experiments with papillary muscles, IBMX $(30 \mu \mathrm{M})$ was added to the tissue bath and allowed to equilibrate before a single cumulative concentration-effect curve to either ( - )-CGP 12177 or $( \pm)$ cyanopindolol was obtained. Experiments were concluded by raising the $\mathrm{Ca}^{2+}$ concentration to $9.25 \mathrm{mM}$.

To determine whether ( - -CGP 12177 and ( \pm )-cyanopindolol caused their effects by stimulation of the same receptor, cumulative concentration effect curves were established to (-)-CGP 12177 in the absence or presence of $1 \mu \mathrm{M}( \pm)$ cyanopindolol in right and left atria and papillary muscles. The equilibrium dissociation constant for $( \pm)$-cyanopindolol $\left(\mathrm{K}_{\mathrm{P}}\right)$ was estimated using equations described for the calculation of the equilibrium dissociation constant for a partial agonist (Marano \& Kaumann, 1976; Lemoine \& Kaumann, 1982). K was estimated from the slope of the plot which relates equieffective concentrations of agonist in the absence $\left(\mathrm{A}_{2}\right)$ and presence $\left(A_{3}\right)$ of a partial agonist $P, A_{2}=I+m A_{3}$, where $I$ is the ordinate intercept. The slope $\mathrm{m}$ of the regression equals
$\mathrm{m}=1-\mathrm{Y}_{\mathrm{P}}$, where the fractional receptor occupancy $\mathrm{Y}_{\mathrm{P}}$ by the partial agonist $\mathrm{P}$ is given by $[\mathrm{P}] /\left([\mathrm{P}]+\mathrm{K}_{\mathrm{P}}\right) \cdot \mathrm{pK}_{\mathrm{P}}$ was calculated from:

$$
\log (1 / \mathrm{m}-1)=\log [\mathrm{P}]-\log \mathrm{K}_{\mathrm{P}}
$$

For experiments with (-)-noradrenaline, left ventricular papillary muscles were incubated with $3 \mu \mathrm{M}$ cocaine, $30 \mu \mathrm{M}$ corticosterone, $1 \mu \mathrm{M}$ phentolamine and $50 \mathrm{nM}$ ICI 118,551 to block neuronal and extraneuronal uptake of $(-)$-noradrenaline, $\alpha$ - and $\beta_{2}$-adrenoceptors respectively in the absence or presence of $3 \mu \mathrm{M}$ CGP 20712A.
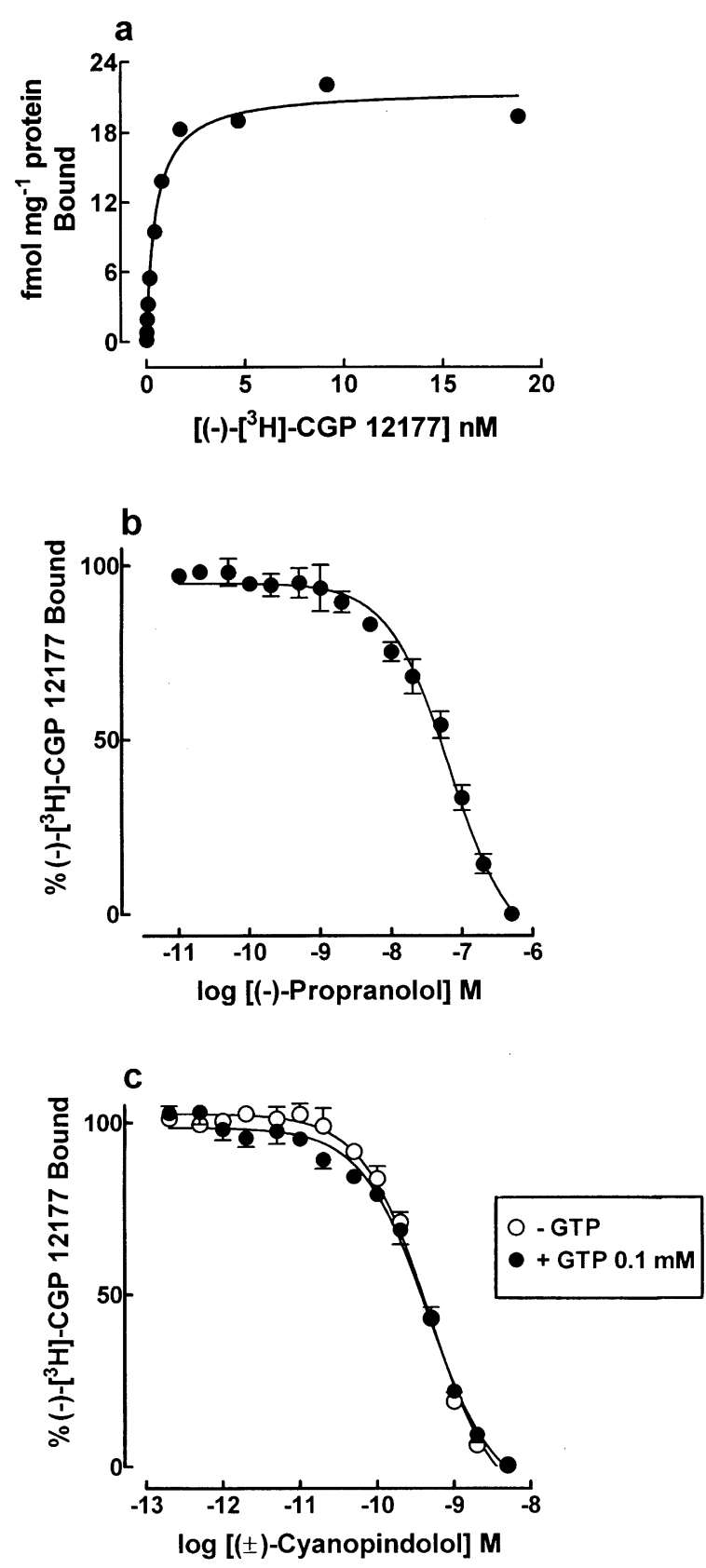

Figure 1 Saturable binding of (-)-[ $\left.{ }^{3} \mathrm{H}\right]-\mathrm{CGP} 12177$ (a) and binding inhibition by (-)-propranolol (b) and ( \pm )-cyanopindolol (c) at $\beta_{1}, \beta_{2}$-adrenoceptors in rat left ventricular membranes. Non-specific binding was determined with $500 \mathrm{~nm}(-)$-propranolol. Competition binding studies between $(-)-\left[{ }^{3} \mathrm{H}\right]-\mathrm{CGP} 12177$ and $( \pm)$-cyanopindolol were done in the absence or presence of $0.1 \mathrm{~mm}$ GTP. The saturation experiment shown in (a) is representative whilst curves in (b) and (c) are mean of 3-5 individual experiments. Vertical lines are s.e.mean. 
Intracellular $\mathrm{Ca}^{2+}$ transients Single rat atrial and ventricular myocytes were isolated from $200-250 \mathrm{~g}$ male Wistar rats as described by Harding et al. (1988) for ventricular myocytes, with slight modifications. Briefly hearts were perfused via the aorta in Langendorff mode at a flow rate of $11 \mathrm{ml} \mathrm{min}^{-1}$ with a modified Krebs-Henseleit solution containing $1 \mathrm{mg} \mathrm{m}^{-1}$ collagenase (Worthington type 2, $300 \mathrm{U} \mathrm{mg}^{-1}$ ) and $0.8 \mathrm{mg} \mathrm{ml}^{-1}$ hyaluronidase. Hearts were then removed from the perfusion apparatus and minced with razor blades before being agitated in the enzyme-containing media for $10 \mathrm{~min}$. Digested tissue was filtered through a fine nylon gauze and the cells obtained were resuspended in a physiological salt solution of the following composition (mM) at room temperature $\left(18-22^{\circ} \mathrm{C}\right): \mathrm{NaCl} 135, \mathrm{KCl} 5, \mathrm{MgCl}_{2} 2$, $\mathrm{NaH}_{2} \mathrm{PO}_{4}$ 0.5, glucose 10, HEPES 10, $\mathrm{NaHCO}_{3} 5, \mathrm{CaCl}_{2} 1$, $\mathrm{pH}$ 7.4. Atrial or ventricular cells were incubated in darkness in the physiological salt solution containing the dual emission fluorescent dye, Indo-1 in its acetoxymethyl ester form (Molecular Probes) at room temperature at a final concentration of $4 \mu \mathrm{M}$. Cells were kept in dye-containing media for $15 \mathrm{~min}$ after which time this medium was exchanged for the physiological salt solution without dye to allow for intracellular deesterification of the dye.

Myocytes were pipetted into a $60 \mu \mathrm{l}$ chamber where they adhered to a coverslip forming the bottom of the chamber. The chamber was then placed on a Nikon inverted microscope (Diaphot) and the cells individually viewed through a $\times 40$ oil immersion fluorescence objective lens (Fluor 40/1.3 oil, Nikon). The myocytes were perfused at a constant rate of $0.2 \mathrm{ml} \mathrm{min}^{-1}$ with physiological salt solution. Changes in solution alone did not result in any changes in the nature of the electrically evoked cellular $\mathrm{Ca}^{2+}$ transients. Myocytes perfused with the physiological salt solution alone did not vary significantly in any of the fluorescent parameters measured over a period of an hour.

Fluorescent dye internalized within the cell was excited by incident light at a wavelength of $340 \mathrm{~nm}$ generated by a mercury lamp. Fluorescence emitted by cells excited in this way was detected, via a dichroic mirror, at 405 and $490 \mathrm{~nm}$ by two photomultiplier tubes (Thorn EMI) and recorded using computer based data acquisition systems (PhoClamp, Life Science Resources, Cambridge, U.K.) as previously described (Freestone et al., 1996).

All experiments on atrial or ventricular myocytes were carried out at room temperature. Myocytes were electrically stimulated to contract using a $15-25 \mathrm{~V}$ stimulus, with $2-5 \mathrm{~ms}$ duration biphasic pulses, at a frequency of $0.3 \mathrm{~Hz}$. Before the start of each experiment cells were stimulated to contract at a frequency of $2-3 \mathrm{~Hz}$ for at least $30 \mathrm{~s}$ to ensure their physiological viability. $\mathrm{Ca}^{2+}$ fluorescence transients monitored by Indo-1 emissions were analysed off-line with a dedicated computer programme (PhoClamp).

\section{Statistics}

Student's paired and unpaired $t$-tests were used to test for significant differences between groups of data, with $P<0.05$ considered significant.

\section{Drugs used}

(-)-CGP 12177 and BRL 37344 were gifts from Dr Jonathan Arch (SmithKline Beecham Pharmaceuticals, Harlow, Essex, U.K.), (-)-bupranolol was a gift from Dr Klaus Sandrock (Sanol-Schwarz, Monheim, Germany), CGP 20712A (CibaGeigy AG, Basel, Switzerland), ( \pm )-carazolol (Boehringer Mannheim GmbH, Mannheim, Germany), ( \pm )-cyanopindolol, (-)-pindolol (Sandoz, Basel, Switzerland), ICI 118,551 (Zeneca, Wilmslow, Cheshire, U.K.), guanosine 5-triphosphate (Boehringer Mannheim, Australia), (-)-propranolol hydrochloride; (-)-isoprenaline bitartrate; bovine serum albumin, (Castle Hill, NSW, Australia); (-)-[33]-CGP 12177 (AMRAD Pharmacia Biotech, Boronia, Australia), IBMX, hyaluronidase (Sigma, St Louis, MO, U.S.A.), Worthington collagenase, type II (Lorne Laboratories, Twyford, Berkshire, U.K.).

\section{Results}

\section{(-)-[3]-CGP 12177 binding to $\beta_{1}, \beta_{2}$-adrenoceptors}

(-)-[ $\left.{ }^{3} \mathrm{H}\right]-C G P 12177(0.01-20 \mathrm{nM})$ binding in rat ventricular homogenates to $\beta_{1}, \beta_{2}$-adrenoceptors was saturable with high affinity $\left(\mathrm{pK}_{\mathrm{D}}\right.$ of 9.32) (Figure 1a, Table 1). (-)-Propranolol and $( \pm)$-cyanopindolol competed with $(-)-\left[{ }^{3} \mathrm{H}\right]-\mathrm{CGP} 12177$ for binding at $\beta_{1}, \beta_{2}$-adrenoceptors (Figure 1b,c, Table 2). The competition binding curve for $( \pm)$-cyanopindolol was unaffected by the absence or presence of $0.1 \mathrm{mM}$ GTP (Figure 1c, Table 2).

\section{(-)-[3H]-CGP 12177 binding to $\beta_{1}, \beta_{2}$ - and putative $\beta_{4}$-adrenoceptors}

The saturation binding curves to (-)-[ $\left.{ }^{3} \mathrm{H}\right]$-CGP 12177 over the concentration range $0.01-200 \mathrm{nM}$ with non-specific binding defined with $20 \mu \mathrm{M}(-)$-CGP 12177 were biphasic and could be resolved into two components (equation 2) corresponding to binding at $\beta_{1}, \beta_{2}$-adrenoceptors and putative $\beta_{4}$-adrenoceptors (Figure 2a, Table 1) with an unconstrained fit and with a

Table 1 Saturation binding experiments with (-)-[3 H]-CGP 12177 at $\beta_{1^{-},}, \beta_{2}$-adrenoceptors (ARs) and the 'putative $\beta_{4}$-adrenoceptor' in rat left ventricle

\begin{tabular}{|c|c|c|c|c|c|c|}
\hline Assay condition & $\mathrm{n}$ & $\begin{array}{c}p K_{D} \\
\beta_{1}, \beta_{2} A R s\end{array}$ & $\begin{array}{l}p K_{D} \\
\beta_{4} A R\end{array}$ & $\begin{array}{c}B_{\max } \beta_{1}, \beta_{2} A R s \\
\left(\mathrm{fmol} \mathrm{mg} \mathrm{mg}^{-1} \text { protein) }\right.\end{array}$ & $\begin{array}{c}B_{\max } \beta_{4} A R \\
\text { (fmol } \mathrm{mg}^{-1} \text { protein) }\end{array}$ & $n_{H}$ \\
\hline A & 5 & $9.32 \pm 0.08$ & - & $22.4 \pm 1.0$ & - & $0.92 \pm 0.05$ \\
\hline \multirow[t]{2}{*}{ B } & 4 & $8.83 \pm 0.03$ & $7.02 \pm 0.11$ & $19.7 \pm 2.2$ & $88.3 \pm 12.8$ & $0.84 \pm 0.03$ \\
\hline & 4 & $9.32 *$ & $7.18 \pm 0.11$ & $13.1 \pm 1.3$ & $86.5 \pm 10.9$ & $0.84 \pm 0.03$ \\
\hline $\mathrm{C}$ & 5 & $9.32 *$ & $7.31 \pm 0.13$ & $20.5 \pm 2.1$ & $47.6 \pm 4.6$ & $1.00 \pm 0.01$ \\
\hline
\end{tabular}

All experiments were carried out in the presence of $0.1 \mathrm{~mm}$ guanosine 5 -triphosphate $(\mathrm{GTP}, 0.1 \mathrm{mM})$. A (-)-[ $\left.{ }^{3} \mathrm{H}\right]-\mathrm{CGP} 121770.01-20$ nM. Non-specific binding determined with $500 \mathrm{nM}(-)$-propranolol. Analysed with equation (1). B (-)-[ $\left.{ }^{3} \mathrm{H}\right]-\mathrm{CGP} 121770.01-200 \mathrm{nM}$. Non-specific binding determined with $20 \mu \mathrm{M}(-)$-CGP 12177. Analysed with equation (2). C (-)-[ $\left.{ }^{3} \mathrm{H}\right]-\mathrm{CGP} 121771-200 \mathrm{~nm}+500 \mathrm{~nm}$ (-)-propranolol. Non-specific binding determined with $20 \mu \mathrm{M}(-)$-CGP 12177. Analysed with equation (3). See text for further explanation. $\mathrm{pK}_{\mathrm{D}}$ and Hill coefficient values $\left(\mathrm{n}_{\mathrm{H}}\right)$ were obtained from $n$ individual experiments and are shown as mean \pm s.e.mean. ${ }^{*} \mathrm{pK} \mathrm{D}_{\mathrm{D}}$ determined from experiments at $\beta_{1^{-}}, \beta_{2}$-adrenoceptors. 


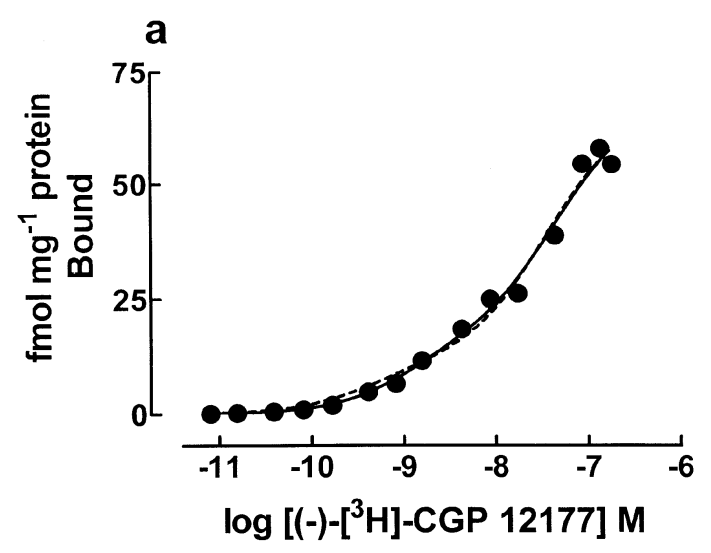

b

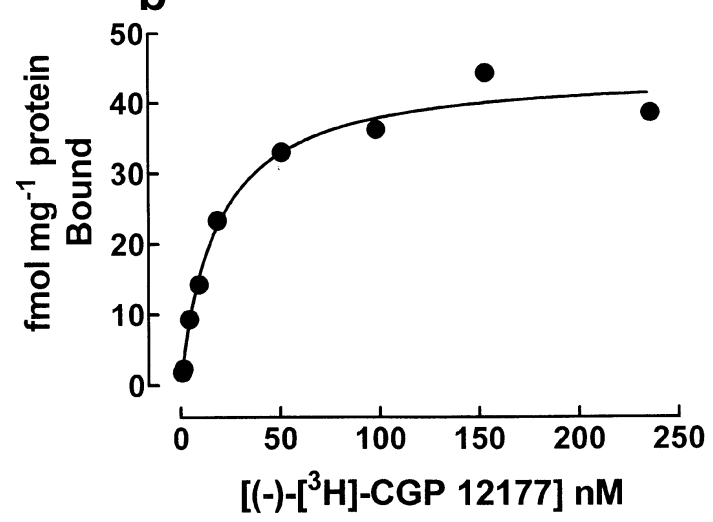

Figure 2 Representative saturation binding experiments at $\beta_{1}, \beta_{2^{-}}$ adrenoceptors and putative $\beta_{4}$-adrenoceptors in rat ventricle. In (a) $0.01-200 \mathrm{nM}(-)-\left[{ }^{3} \mathrm{H}\right]-\mathrm{CGP} 12177$ binding was carried out in the absence or presence of $20 \mu \mathrm{M}(-)$-CGP 12177 to define non-specific binding whilst in (b) $1-200 \mathrm{nM}(-)-\left[{ }^{3} \mathrm{H}\right]-C G P 12177$ was used in the presence of $500 \mathrm{~nm}(-)$-propranolol in the absence or presence of $20 \mu \mathrm{M}(-)$-CGP 12177 to define non-specific binding. In (a), the fit represented by the dashed line was constrained to $\mathrm{pK}_{\mathrm{D}} 9.32$ at $\beta_{1}, \beta_{2^{-}}$ adrenoceptors while the solid line was unconstrained. Experiments were performed in the presence of $0.1 \mathrm{mM}$ GTP.

constrained fit with $\mathrm{pK}_{\mathrm{D}}$ fixed at 9.32 for $\beta_{1^{-}}, \beta_{2}$-adrenoceptors. The estimated $\mathrm{pK}_{\mathrm{D}}$ and $\mathrm{B}_{\max }$ for $(-)-\left[{ }^{3} \mathrm{H}\right]$-CGP 12177 for putative $\beta_{4}$-adrenoceptors was 2 orders of magnitude greater and $2.1-6.7$ fold greater respectively than at $\beta_{1}, \beta_{2}$-adrenoceptors (Table 1).

(-)-Propranolol competed for (-)-[ $\left.{ }^{3} \mathrm{H}\right]-\mathrm{CGP} 12177$ binding with non-specific binding determined with $20 \mu \mathrm{M}(-)$-CGP 12177 (Figure 3a). The binding curve was resolved into two components (equation 5) corresponding to $\beta_{1}, \beta_{2}$-adrenoceptors and putative $\beta_{4}$-adrenoceptors (Table 2 ). We then used $500 \mathrm{nM}(-)$-propranolol to block $\beta_{1}, \beta_{2}$-adrenoceptors in subsequent experiments.

Saturation binding experiments were carried out with (-)$\left[{ }^{3} \mathrm{H}\right]$-CGP 12177 in the presence of $500 \mathrm{nM}(-)$-propranolol (Figure 2b). The curve could be resolved into two components using equation (3) with a constrained fit with $\mathrm{pK}_{\mathrm{D}}$ fixed at 9.3 for $\beta_{1}, \beta_{2}$-adrenoceptors (Table 1).

The antagonist ( - )-bupranolol bound to $\beta_{1}, \beta_{2}$-adrenoceptors with high affinity $\left(\mathrm{pK}_{\mathrm{i}}\right.$ 9.7) and the putative $\beta_{4^{-}}$ adrenoceptor with lower affinity $\left(\mathrm{pK}_{\mathrm{i}} 5.8\right)$ (Figure $3 \mathrm{~b}$, Table 2). Binding was unaffected by the absence or presence of $0.1 \mathrm{~mm}$ GTP (Figure 3b, Table 2).

(土)-Cyanopindolol competed with $48-61 \mathrm{nM}(-)-\left[{ }^{3} \mathrm{H}\right]-$ CGP 12177 binding in the presence of $500 \mathrm{nM}(-)$ -
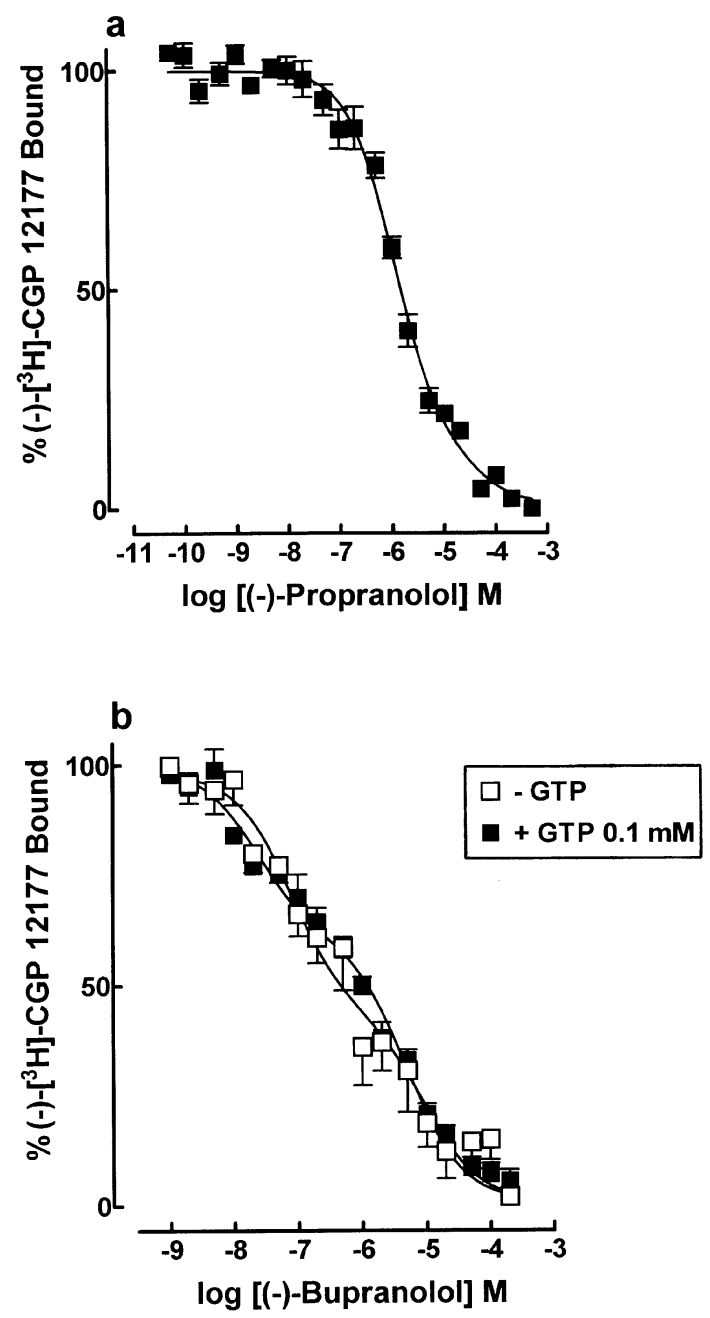

Figure 3 Competition binding experiments between 50-63 nм (-)$\left[{ }^{3} \mathrm{H}\right]$-CGP 12177 and (a) (-)-propranolol and (b) (-)-bupranolol in the absence or presence of $0.1 \mathrm{~mm}$ GTP in rat left ventricle. Experiments with $(-)$-bupranolol were carried out in the presence of $500 \mathrm{nM}(-)$-propranolol. Non-specific binding was determined with $20 \mu \mathrm{M}(-)$-CGP 12177. Binding isotherms were analysed for two populations, $\beta_{1}, \beta_{2}$-adrenoceptors and putative $\beta_{4}$-adrenoceptors with equation (5). Curves are mean of $4-7$ individual experiments. Vertical lines are s.e.mean.

propranolol at three binding sites which were resolved with equation (5) $\left(\mathrm{pK}_{\mathrm{i}} 10.0, \% \beta_{1,2} 33\right)$, an intermediate affinity site $\left(\mathrm{pK}_{\mathrm{i}} 7.4, \% \beta_{4 \mathrm{H}} 38\right)$ and another low affinity site $\left(\mathrm{pK}_{\mathrm{i}} 5.1, \% \beta_{4 \mathrm{~L}}\right.$ 29) (Figure 4a, Table 2). Binding was unaffected by the absence or presence of GTP (Figure 4a, Table 2). We then reanalysed binding curves for $( \pm)$-cyanopindolol, $(-)$-pindolol and $( \pm)$ carazolol in rat atria, also with equation (5) which we had previously published (Sarsero et al., 1998). Radioligand binding was carried out in the presence of $(-)$-propranolol which had an affinity $\left(\mathrm{pK}_{\mathrm{i}}\right)$ of 8.6 for $\beta_{1}, \beta_{2}$-adrenoceptors (Table 3 ). Each of these curves was characterized by a higher affinity component corresponding to $\beta_{1}, \beta_{2}$-adrenoceptors, an 'intermediate' component $\left(\beta_{4 \mathrm{H}}\right)$ and another 'low' affinity component $\left(\beta_{4 \mathrm{~L}}\right)$ (Figure $4 \mathrm{~b}-\mathrm{d}$, Table 3 ).

Positive inotropic effects of (-)-CGP 12177 and $( \pm)$-cyanopindolol in rat left ventricular papillary muscles

The cumulative addition of (-)-CGP 12177 or ( \pm )cyanopindolol (both $2 \mathrm{nM}-60 \mu \mathrm{M}, n=4$ ) did not change 
Table 2 Competition binding data between (-)-[3]-CGP 12177 and (-)-propranolol, ( \pm )-cyanopindolol and ( - )-bupranolol at $\beta_{1^{-}}$, $\beta_{2}$-adrenoceptors and 'putative $\beta_{4}$-adrenoceptors' in rat ventricle

\begin{tabular}{|c|c|c|c|c|c|c|}
\hline & \multirow[b]{2}{*}{$\mathrm{n}$} & \multirow[b]{2}{*}{$n_{H}$} & \multicolumn{2}{|c|}{$\beta_{1^{-}}, \beta_{2}$-adrenoceptors } & \multicolumn{2}{|c|}{ 'putative $\beta_{4}$-adrenoceptors' } \\
\hline & & & $p K i$ & $\%$ & $p K i$ & $\%$ \\
\hline + GTP (0.1 mM) & & & & & & \\
\hline (-)-Propranolol* & 5 & $1.07 \pm 0.17$ & $\begin{array}{l}8.00 \pm 0.07 \\
841+0.06\end{array}$ & 100 & & \\
\hline (-)-Propranolol** & $\begin{array}{l}4 \\
3\end{array}$ & $\begin{array}{l}0.81 \pm 0.04 \\
1.08+0.06\end{array}$ & $\begin{array}{r}8.41 \pm 0.06 \\
10.03+0.07\end{array}$ & $29.5 \pm 1.4$ & $5.70 \pm 0.07$ & $70.5 \pm 1.4$ \\
\hline ( \pm )-Cyanopindolol ${ }^{* * *}$ & 14 & $0.43 \pm 0.02$ & 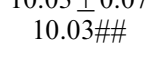 & $33.2 \pm 3.9$ & $\begin{array}{l}7.35 \pm 0.18(\mathrm{H}) \# \# \# \\
5.13 \pm 0.13(\mathrm{~L})\end{array}$ & $\begin{array}{l}38.3 \pm 4.5(\mathrm{H}) \\
28.5 \pm 3.0(\mathrm{~L})\end{array}$ \\
\hline (-)-Bupranolol\# & 6 & $0.48 \pm 0.02$ & $9.70 \pm 0.31$ & $33.5 \pm 4.4$ & $5.78 \pm 0.07$ & $66.5 \pm 4.4$ \\
\hline $\begin{array}{l}- \text { GTP } \\
( \pm) \text {-Cyanopindolol* }\end{array}$ & 3 & $1.06 \pm 0.03$ & $10.00 \pm 0.01$ & 100 & & \\
\hline$( \pm)$-Cyanopindolol ${ }^{* * *}$ & 5 & $0.43 \pm 0.09$ & $10.00 \# \#$ & $29.3 \pm 3.1$ & $\begin{array}{l}7.44 \pm 0.41(\mathrm{H}) \\
5.00 \pm 0.26(\mathrm{~L})\end{array}$ & $\begin{array}{l}41.8 \pm 6.3(\mathrm{H}) \\
28.9 \pm 4.8(\mathrm{~L})\end{array}$ \\
\hline (-)-Bupranolol\# & 7 & $0.60 \pm 0.10$ & $9.47 \pm 0.26$ & $38.0 \pm 7.0$ & $5.79 \pm 0.39$ & $62.0 \pm 7.0$ \\
\hline
\end{tabular}

* (-)-[3 $\left.{ }^{3} \mathrm{H}\right]$-CGP 12177 1.1-1.7 nM. Non-specific binding determined with $500 \mathrm{~nm}(-)$-propranolol. Analysed with equation (4). $* *(-)-\left[{ }^{3} \mathrm{H}\right]$-CGP $1217750-53 \mathrm{nM}$. Non-specific binding determined with $20 \mu \mathrm{M}(-)$-CGP 12177. Analysed with equation $(5)$. *** $(-)$ $\left[{ }^{3} \mathrm{H}\right]$-CGP $1217748-61 \mathrm{nM}+500 \mathrm{~nm}(-)$-propranolol. Non-specific binding determined with $20 \mu \mathrm{M}(-)$-CGP 12177 . Analysed with equation (5). \#(-)-[33]-CGP $1217750-63 \mathrm{~nm}+500 \mathrm{~nm}(-)$-propranolol. Non-specific binding determined with $20 \mu \mathrm{M}(-)$-CGP 12177. Analysed with equation (5). $\# \# \mathrm{pK}_{\mathrm{i}}$ derived from separate experiments at $\beta_{1^{-}}, \beta_{2}$-adrenoceptors. \#\#\#(H) and (L) refer to $\beta_{4 \mathrm{H}}$ and $\beta_{4 \mathrm{~L}}$. Affinity $\left(\mathrm{pK}_{\mathrm{i}}\right)$ and pseudo Hill coefficient values $\left(\mathrm{n}_{\mathrm{H}}\right)$ were obtained from $n$ individual experiments and are shown as mean \pm s.e.mean. $\%$ : percentage of total receptor population.

Table 3 Competition binding data between (-)-[33]-CGP 12177 and (-)-propranolol, ( \pm )-cyanopindolol, $(-)$-pindolol and $( \pm)$ carazolol at $\beta_{1^{-}}, \beta_{2}$-adrenoceptors and the 'putative $\beta_{4}$-adrenoceptor' in rat atrium

\begin{tabular}{|c|c|c|c|c|c|c|}
\hline \multirow{5}{*}{ (-)-Propranolol* } & \multirow{4}{*}{$\begin{array}{l}\mathrm{n} \\
4\end{array}$} & \multirow[b]{2}{*}{$n_{H}$} & \multicolumn{2}{|c|}{$\beta_{1^{-}}, \beta_{2^{-}}$adrenoceptors } & \multicolumn{2}{|c|}{ 'putative $\beta_{4}$-adrenoceptors' } \\
\hline & & & $p K i$ & $\%$ & $p K i$ & $\%$ \\
\hline & & $0.52 \pm 0.01$ & $8.56 \pm 0.07$ & $34.9 \pm 2.8$ & $5.30 \pm 0.06$ & $65.1 \pm 2.8$ \\
\hline & & & \multicolumn{2}{|c|}{$\beta_{1}$-adrenoceptors\# } & \multicolumn{2}{|c|}{ 'putative $\beta_{4}$-adrenoceptors' } \\
\hline & $\mathrm{n}$ & $n_{H}$ & $p K i$ & $\%$ & $p K i$ & $\%$ \\
\hline$( \pm)$-Cyanopindolol** & 6 & $0.65 \pm 0.09$ & 10.75 & $27.4 \pm 1.7$ & $\begin{array}{l}7.48 \pm 0.20(\mathrm{H}) \# \# \\
4.97 \pm 0.10(\mathrm{~L})\end{array}$ & $\begin{array}{l}48.1 \pm 5.8(\mathrm{H}) \\
24.5 \pm 5.5(\mathrm{~L})\end{array}$ \\
\hline (-)-Pindolol** & 6 & $0.77 \pm 0.16$ & 8.69 & $28.0 \pm 2.0$ & $\begin{array}{l}7.13 \pm 0.27(\mathrm{H}) \\
4.07 \pm 0.47(\mathrm{~L})\end{array}$ & $\begin{array}{l}58.5 \pm 4.4(\mathrm{H}) \\
13.5 \pm 2.5(\mathrm{~L})\end{array}$ \\
\hline$( \pm)$-Carazolol** & 6 & $0.85 \pm 0.21$ & 9.96 & $31.0 \pm 6.8$ & $\begin{array}{l}7.74 \pm 0.19(\mathrm{H}) \\
4.04 \pm 0.39(\mathrm{~L})\end{array}$ & $\begin{array}{r}64.4 \pm 6.8(\mathrm{H}) \\
4.6 \pm 1.6(\mathrm{~L})\end{array}$ \\
\hline
\end{tabular}

All experiments were carried out in the presence of $0.1 \mathrm{~mm}$ guanosine 5-triphosphate $(\mathrm{GTP}, 0.1 \mathrm{~mm}) *(-)-\left[{ }^{3} \mathrm{H}\right]-\mathrm{CGP} 1217751-52 \mathrm{nM}$ Non-specific binding determined with $20 \mu \mathrm{M}(-)$-CGP 12177. Analysed with equation (5). ** (-)-[ $\left.{ }^{3} \mathrm{H}\right]-\mathrm{CGP} 1217747-57 \mathrm{nM}+500$ $\mathrm{nM}(-)$-propranolol. Non-specific binding determined with $20 \mu \mathrm{M}(-)$-CGP 12177. Analysed with equation (5). \#pK $\mathrm{i}_{\mathrm{i}}$ determined at the $\beta_{1}$-adrenoceptor from binding using $(-)$ - $\left.{ }^{3} \mathrm{H}\right]$-CGP 12177 in the presence of the $\beta_{2}$-adrenoceptor antagonist ICI 118 , 551 50 nM, data from Sarsero et al. (1998). \#\#(H) and (L) refer to $\beta_{4 \mathrm{H}}$ and $\beta_{4 \mathrm{~L}}$. Affinity $\left(\mathrm{pK}_{\mathrm{i}}\right)$ and pseudo Hill coefficient values $\left(\mathrm{n}_{\mathrm{H}}\right)$ were obtained from $n$ individual experiments and are shown as mean \pm s.e.mean. \%: percentage of total receptor population.

contractile force in left ventricular papillary muscle as described previously (Kaumann \& Molenaar, 1996). The single addition of $30 \mu \mathrm{M}$ IBMX caused an increase in contractile force ranging from $0.1-0.4 \mathrm{mN}$ (Table 4$)$. In the presence of $30 \mu \mathrm{M}$ IBMX, (-)-CGP 12177 and $( \pm)$-cyanopindolol caused concentration dependent positive inotropic effects (Figure 5a,c, Table 4). The positive inotropic effects of (-)-CGP 12177 were associated with reductions in the time to reach $50 \%$ relaxation (Figure 5b). Cumulative concentration-effect curves to (-)CGP 12177 and ( \pm )-cyanopindolol were shifted to the right by $1 \mu \mathrm{M}(-)$-bupranolol with affinity $\left(\mathrm{pK}_{\mathrm{B}}\right)$ values of 7.0 and 6.7 and $3 \mu \mathrm{M}$ CGP $20712 \mathrm{~A}$ with affinity values $\left(\mathrm{pK}_{\mathrm{B}}\right)$ of 6.6 and 6.3 (Figure 5a,c, Table 4).

In radioligand binding studies, $( \pm)$-cyanopindolol competed with $(-)-\left[{ }^{3} \mathrm{H}\right]-\mathrm{CGP} 12177$ for three receptor populations. One we identified as a $\beta_{1}, \beta_{2}$-adrenoceptor population. We were interested to know which receptors corresponded to the functional putative $\beta_{4}$-adrenoceptor. Cumulative concentration-effect curves were established to (-)-CGP 12177 in the absence or presence of $1 \mu \mathrm{M}( \pm)$-cyanopindolol. In each tissue,
( \pm )-cyanopindolol caused cardiostimulant effects and also produced a rightward shift of the (-)-CGP 12177 concentration-effect curve (Figure 6). $\mathrm{pK}_{\mathrm{P}}$ values (equation (6)) for $( \pm$ )cyanopindolol were 7.0 (papillary muscle), 7.3 (right atrium) and 7.4 (left atrium). These values correspond to the affinity value $\left(\mathrm{pK}_{\mathrm{i}}, \beta_{4 \mathrm{H}}\right)$ of 7.4 for $( \pm)$-cyanopindolol obtained in competition binding experiments with $(-)-\left[{ }^{3} \mathrm{H}\right]-\mathrm{CGP} 12177$. The affinity values for $( \pm)$-cyanopindolol were used to construct fractional receptor occupancy curves which overlapped the concentration-effect curves in rat right atrium, left atrium and left ventricular papillary muscle (Figure 6).

\section{Lack of effect of BRL 37344 in rat left ventricular papillary muscles}

The addition of $30 \mu \mathrm{M}$ IBMX caused variable changes in contractile force in 14 left ventricular papillary muscles (mean increase, $0.21 \pm 0.10 \mathrm{mN}$, range -0.125 to $1.4 \mathrm{mN}, n=14$ ) with measurements taken immediately prior to addition of BRL 37344. The addition of BRL $37344(1 \mu \mathrm{M})$ had no effect 
a
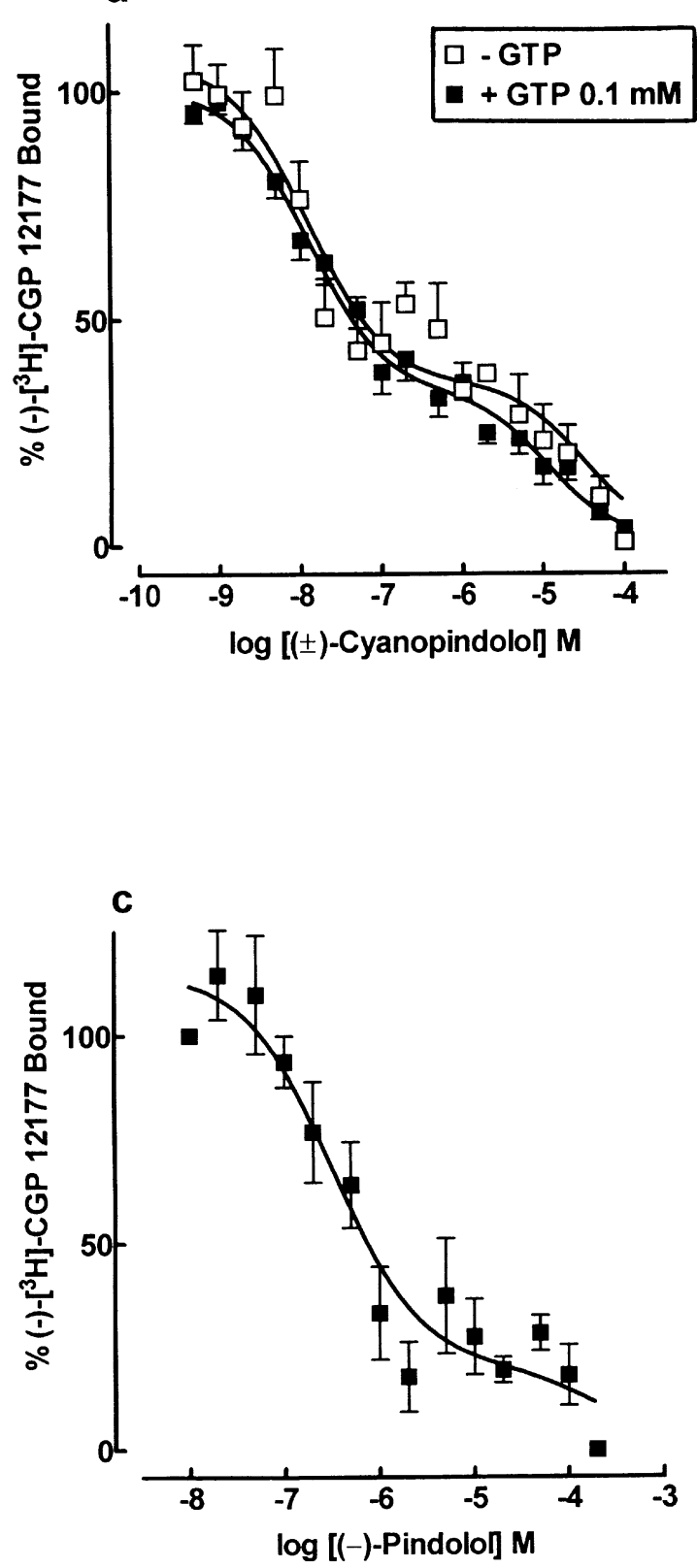

b
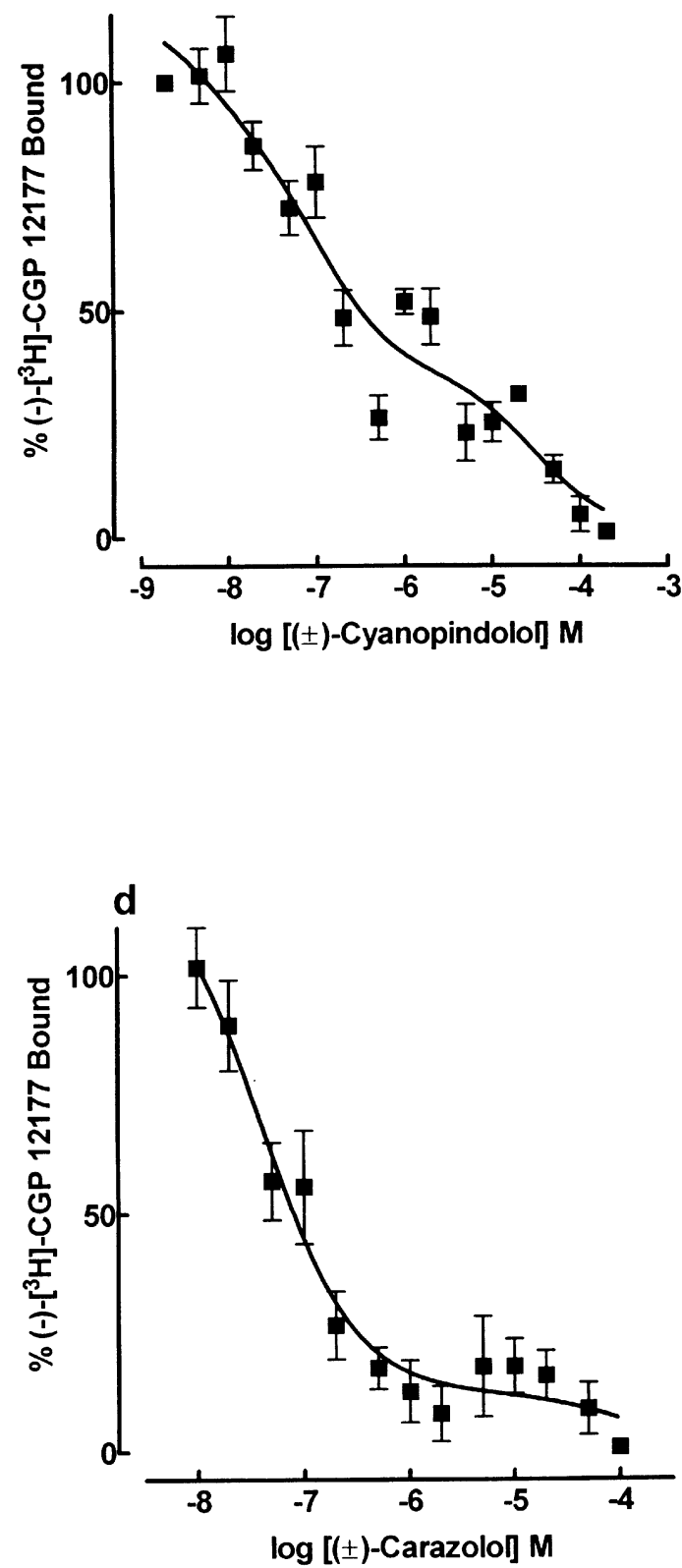

Figure 4 Competition binding experiments between 48-61 nM (-)-[ $\left.{ }^{3} \mathrm{H}\right]-\mathrm{CGP} 12177$ and (a) ( \pm )-cyanopindolol in the absence or presence of $0.1 \mathrm{mM}$ GTP in rat left ventricle membranes. Also shown are competition binding experiments between $\left.(-)-{ }^{3} \mathrm{H}\right]-\mathrm{CGP}$ 12177 and (b) ( \pm )-cyanopindolol, (c) ( - )-pindolol and (d) ( \pm )-carazolol in rat atrial membranes (data from Sarsero et al., 1998). Experiments were carried out in the presence of $500 \mathrm{nM}(-)$-propranolol. Non-specific binding was determined with $20 \mu \mathrm{M}(-)$ CGP 12177. Curves were fitted for three populations/states, $\beta_{1}, \beta_{2}$-adrenoceptors, putative $\beta_{4 \mathrm{H}^{-}}$and putative $\beta_{4 \mathrm{~L}}$-adrenoceptors with equation (5). Curves are mean of 5-14 individual experiments. Vertical lines are s.e.mean.

Table 4 Potency $\left(\mathrm{pEC}_{50}\right)$ and maximal effects $\left(\mathrm{E}_{\max }\right)$ of agonists at the 'putative $\beta_{4}$-adrenoceptor' in rat left ventricular papillary muscle in the presence of $30 \mu \mathrm{M}$ 3-isobuty-1-methylxanthine (IBMX). Effects of antagonists $\left(\mathrm{pK}_{\mathrm{B}}\right)$

\begin{tabular}{|c|c|c|c|c|c|c|c|c|}
\hline Condition & $\mathrm{n}$ & $\begin{array}{l}\text { Basal } \\
\text { force* } \\
(\mathrm{mN})\end{array}$ & $\begin{array}{c}\text { Basal force } \\
+\quad I B M X \\
(\mathrm{mN})\end{array}$ & Agonist & $\begin{array}{l}E_{\max }^{* *} \\
(\Delta \mathrm{mN})\end{array}$ & $p E C_{50}$ & $\begin{array}{c}p K_{B} \\
(-) \text {-Bupranolol }\end{array}$ & $\begin{array}{c}p K_{B} \\
C G P 20712 A\end{array}$ \\
\hline$(-)$-Propranolol & 6 & $1.1 \pm 0.3$ & $1.3 \pm 0.4$ & $(-)$-CGP 12177 & $1.6 \pm 0.4$ & $7.6 \pm 0.1$ & - & - \\
\hline$+(-)$-bupranolol $1 \mu \mathrm{M}$ & 5 & $5.5 \pm 2.5$ & $5.9 \pm 2.5$ & (-)-CGP 12177 & $2.8 \pm 1.1$ & $6.6 \pm 0.1$ & $7.0 \pm 0.1$ & - \\
\hline+ CGP 20712A $3 \mu \mathrm{M}$ & 8 & $1.0 \pm 0.1$ & $1.1 \pm 0.1$ & (-)-CGP 12177 & $1.4 \pm 0.3$ & $6.5 \pm 0.1$ & - & $6.6 \pm 0.1$ \\
\hline (-)-Propranolol & 10 & $1.5 \pm 0.3$ & $1.9 \pm 0.4$ & $( \pm)$-Cyanopindolol & $0.7 \pm 0.1$ & $7.0 \pm 0.08$ & - & - \\
\hline$+(-)$-bupranolol $1 \mu \mathrm{M}$ & 9 & $1.8 \pm 0.5$ & $2.0 \pm 0.4$ & $( \pm)$-Cyanopindolol & $0.9 \pm 0.2$ & $6.2 \pm 0.1$ & $6.7 \pm 0.1$ & - \\
\hline+ CGP 20712A $3 \mu \mathrm{M}$ & 8 & $2.3 \pm 0.6$ & $2.6 \pm 0.4$ & ( \pm )-Cyanopindolol & $0.7 \pm 0.2$ & $6.2 \pm 0.1$ & - & $6.3 \pm 0.1$ \\
\hline
\end{tabular}

*Force expressed in absolute $\mathrm{mN}$ after 60 min incubation with $200 \mathrm{nM}(-)$-propranolol alone or with either $1 \mu \mathrm{M}(-)$-bupranolol or 3 $\mu \mathrm{M}$ CGP 20712A. ** Increase in contractile force (measured above basal force $+30 \mu \mathrm{M}$ IBMX) caused by a maximal concentration of agonist. 
on contractile force. (-)-CGP $12177(1 \mu \mathrm{M})$ caused an increase in contractile force in the presence of IBMX (Figure 7) which was unaffected by the presence of $1 \mu \mathrm{M}$ BRL $37344((-)$-CGP $121773.9 \pm 0.7 \mathrm{mN}, \quad n=6 ; \quad(-)$-CGP $12177+\mathrm{BRL} 37344$ $3.0 \pm 0.6 \mathrm{mN}$, values given as increases in contractile force, $n=8, \quad P=0.3$ ). A representative experiment is shown in Figure 7.
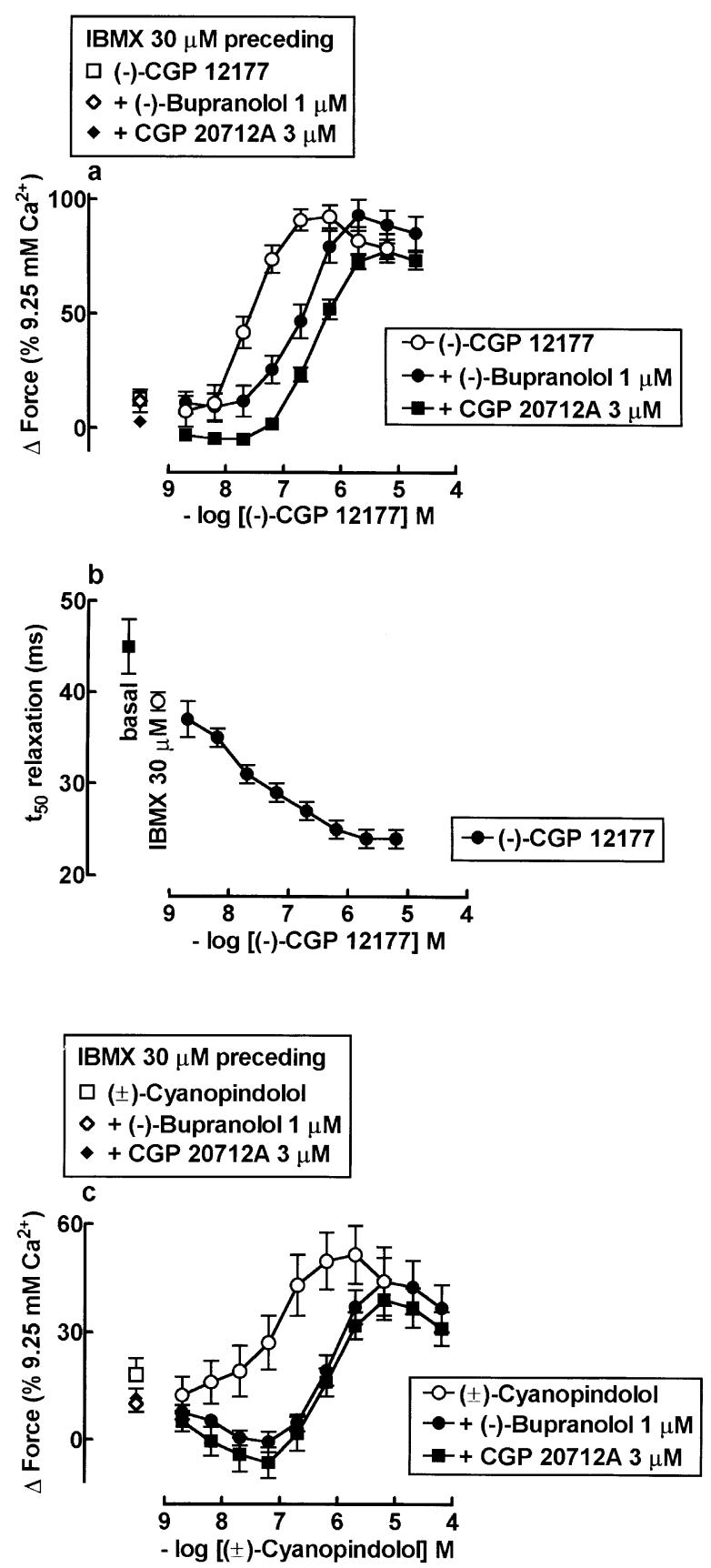

Figure 5 Antagonism of the positive inotropic effects of (-)-CGP 12177 (a) and $( \pm$ )-cyanopindolol (c) by $1 \mu \mathrm{M}(-)$-bupranolol and $3 \mu \mathrm{M}$ CGP $20712 \mathrm{~A}$ in electrically paced rat left ventricular papillary muscle preparations. Concentration-dependent positive lusitropic effects of (-)-CGP 12177 (b). Cumulative concentration-effect curves were carried out in the presence of the phosphodiesterase inhibitor IBMX $(30 \mu \mathrm{M})$ which caused an increase in contractile force. All experiments were carried out in the presence of $200 \mathrm{~nm}$ (-)propranolol. Inotropic responses are expressed as a percentage of the effect caused by $9.25 \mathrm{mM} \mathrm{Ca}^{2+}$. Shown are mean curves from $5-$ 10 individual experiments and vertical lines show s.e.mean.
Positive inotropic effects of (-)-noradrenaline in rat ventricular papillary muscles: blockade by CGP 20712A

In the presence of $30 \mu \mathrm{M}$ IBMX, $\alpha$ - and $\beta_{2}$-adrenoceptor blockade with $1 \mu \mathrm{M}$ phentolamine and $50 \mathrm{nM}$ ICI 118,551 respectively, (-)-noradrenaline caused an increase in contractile force $\left(\mathrm{pEC}_{50} 8.5 \pm 0.1, n=6\right)$. CGP 20712A $3 \mu \mathrm{M}$ caused a $3.33 \pm 0.16 \mathrm{log}$ unit rightward shift of the concentration-effect curve to (-)-noradrenaline (Figure 8).

\section{$\mathrm{Ca}^{2+}$ transients are shorter in atrial than ventricular myocytes}

The time to reach $50 \%$ decrease of the $\mathrm{Ca}^{2+}$ transient $\left(\mathrm{t}_{50}\right)$ in electrically stimulated atrial myocytes $(218 \pm 11 \mathrm{~ms}, n=74$ cells from 42 hearts, Table 5) was quicker than in ventricular myocytes $(261 \pm 11 \mathrm{~ms}, n=49$ cells from 24 hearts, Table 6 , $P=0.01)$.

(-)-CGP 12177 causes increased $\mathrm{Ca}^{2+}$ transients and arrhythmic transients in atrial myocytes

(-)-CGP $12177(10 \mathrm{nM}-10 \mu \mathrm{M})$, incubated $10-15 \mathrm{~min}$, caused steady state increases in $\mathrm{Ca}^{2+}$ transient amplitude but only inconsistently and non-significantly reduced the time to reach a $50 \%$ decrease in the transient (Figure 9; Table 5). (-)CGP $12177(10 \mathrm{nM}-10 \mu \mathrm{M})$ caused arrhythmic $\mathrm{Ca}^{2+}$ transients in some myocytes (Figure 10, Table 5) which could be divided into early or late aftertransients (extrasystole) (Figure 10, Table 5). The early aftertransient was associated with a paced transient while the late aftertransient occurred between two paced transients. The increase in transient amplitude and arrhythmic transients were resistant to blockade by $200 \mathrm{nM}$ (-)-propranolol (Table 5). (-)-Isoprenaline $100 \mathrm{nM}$ caused similar increases of $\mathrm{Ca}^{2+}$ transients to the maximum effects of (-)-CGP 12177 but, unlike (-)-CGP 12177, it significantly $(P=0.02)$ reduced the $\mathrm{t}_{50}$ for recovery of diastolic $\mathrm{Ca}^{2+}$ (Figure 9, Table 5).

\section{(-)-CGP 12177 increases $\mathrm{Ca}^{2+}$ transients in} ventricular myocytes: enhancement by IBMX

(-)-CGP $12177(1 \mu \mathrm{M})$ caused only a small increase in $\mathrm{Ca}^{2+}$ transient amplitude (Figure 11, Table 6). IBMX (1 $\mu \mathrm{M})$ on its own had no effect on transients $(-1.6 \pm 2.1 \%$ change from control transients, $n=7$ cells from 5 hearts). However, in the presence of $1 \mu \mathrm{M}$ IBMX, (-)-CGP 12177 (1 $\mu \mathrm{M})$ nearly doubled the transient amplitude and reduced the time to reach a $50 \%$ reduction in the $\mathrm{Ca}^{2+}$ transient (Figures 11 and 12, Table 6). The effects of $1 \mu \mathrm{M}(-)$-CGP $12177+1 \mu \mathrm{M}$ IBMX were not significantly affected by the presence of $200 \mathrm{nM}(-)$ propranolol (Table 6). In some myocytes (-)-CGP 12177 caused arrhythmic transients consisting of early aftertransients and late aftertransients (Figure 12, Table 6). (-)-Isoprenaline (100 nM in the absence of IBMX and (-)-propranolol) also caused an increase in transient amplitude and hastened the decline of the transient (Figure 11, Table 6) and also elicited arrhythmic transients in several myocytes (Table 6).

\section{Discussion}

In a previous study (Kaumann \& Molenaar, 1996) we reported that (-)-CGP 12177 and ( \pm )-cyanopindolol caused positive inotropic effects in rat left atria but not in rat left ventricular 
papillary muscle, suggesting the existence of putative $\beta_{4^{-}}$ adrenoceptors in atrium but not ventricle. We have now carried out further investigations in rat ventricle and have obtained evidence from radioligand binding, in vitro contrac-

Table 5 Effects of (-)-CGP 12177 and (-)-isoprenaline on $\mathrm{Ca}^{2+}$ transient amplitude in rat atrial myocytes

\begin{tabular}{|c|c|c|c|c|c|c|c|c|}
\hline \multirow[b]{2}{*}{$\begin{array}{l}\text { Experimental } \\
\text { condition }\end{array}$} & \multirow[b]{2}{*}{$n^{*}$} & \multirow[b]{2}{*}{$\begin{array}{l}\% \text { increase in } \\
\text { fluorescence }\end{array}$} & \multirow[b]{2}{*}{$\mathrm{P} * *$} & \multirow[b]{2}{*}{$t_{50} * * *$} & \multirow[b]{2}{*}{$\mathrm{P} * *$} & \multicolumn{3}{|c|}{ Arrhythmias } \\
\hline & & & & & & $\begin{array}{c}\text { Late } \\
\text { after } \\
\text { transient }\end{array}$ & $\begin{array}{c}\text { Early } \\
\text { after } \\
\text { transient }\end{array}$ & $\begin{array}{c}\text { Non } \\
\text { arrhythmic } \\
\text { cells }\end{array}$ \\
\hline$(-)$-CGP 12177 & & & & & & & & \\
\hline $10 \mathrm{~nm}$ & $3(2)$ & $47.9 \pm 22.7$ & 0.1 & $\begin{array}{l}\text { B } 282 \pm 44 \text { (3) } \\
226 \pm 36\end{array}$ & 0.38 & 2 & 0 & 1 \\
\hline $100 \mathrm{~nm}$ & $8(4)$ & $66.1 \pm 19.4$ & 0.01 & $\begin{array}{l}\text { B } 216 \pm 33 \text { (5) } \\
167 \pm 3\end{array}$ & 0.18 & 5 & 0 & 3 \\
\hline $1 \mu \mathrm{M}$ & $10(5)$ & $89.2 \pm 20.7$ & 0.001 & $\begin{array}{c}\text { В } 193 \pm 33(10) \\
160 \pm 29\end{array}$ & 0.46 & 7 & 2 & 1 \\
\hline $10 \mu \mathrm{M}$ & $9(5)$ & $91.6 \pm 24.2$ & 0.004 & $\begin{array}{l}\text { В } 207 \pm 33(8) \\
158 \pm 18\end{array}$ & 0.21 & 5 & 3 & 1 \\
\hline $\begin{array}{l}+200 \mathrm{~nm}(-) \text {-Propranolol } \\
10 \mathrm{nM}\end{array}$ & $7(4)$ & $16.6 \pm 4.8 \%$ & 0.007 & $\begin{array}{c}\text { В } 197 \pm 29(5)+t \\
177 \pm 29\end{array}$ & 0.64 & 2 & 0 & 5 \\
\hline $100 \mathrm{~nm}$ & $10(6)$ & $30.5 \pm 10.5 \mathrm{t}$ & 0.003 & $\begin{array}{l}\text { В } 248 \pm 43(8)+4 \\
215 \pm 29\end{array}$ & 0.54 & 6 & 2 & 4 \\
\hline $1 \mu \mathrm{M}$ & $14(5)$ & $56.0 \pm 14.0$ 林 & 0.03 & $\begin{array}{c}\text { B } 220 \pm 12(6)+4 \\
215 \pm 26\end{array}$ & 0.86 & 7 & 3 & 4 \\
\hline $10 \mu \mathrm{M}$ & $9(3)$ & $57.6 \pm 13.8 \mathrm{tt}$ & 0.06 & $\begin{array}{l}\text { B } 198 \pm 24(5)+\mathrm{t} \\
176 \pm 13\end{array}$ & 0.43 & 4 & 1 & 4 \\
\hline $\begin{array}{l}\text { (-)-Isoprenaline } \\
100 \mathrm{~nm}\end{array}$ & $14(8)$ & $67.0 \pm 12.3$ & 0.01 & $\begin{array}{c}\text { В } 233 \pm 29(14)+t \\
154 \pm 11\end{array}$ & 0.02 & 9 & 3 & 3 \\
\hline
\end{tabular}

* $n$ values are numbers of cells from $n$ hearts between parentheses. $* * P$ value compared to 0 (fluorescence amplitude) or basal ( $\mathrm{t}_{50}$ ). $* * *$ Time $(\mathrm{ms})$ to reach $50 \%$ decrease in $\mathrm{Ca}^{2+}$ fluorescence transients, $\mathrm{B}$ is basal value prior to incubation with drug. $\$$ Number of cells. $\$$ No difference between (-)-CGP 12177 and (-)-CGP $12177+200 \mathrm{nM}(-)$-propranolol, $P>0.06$. Arrhythmias were observed after measurments of increase in $\mathrm{Ca}^{2+}$ transient amplitude and reduction in $\mathrm{t}_{50}$ were taken.
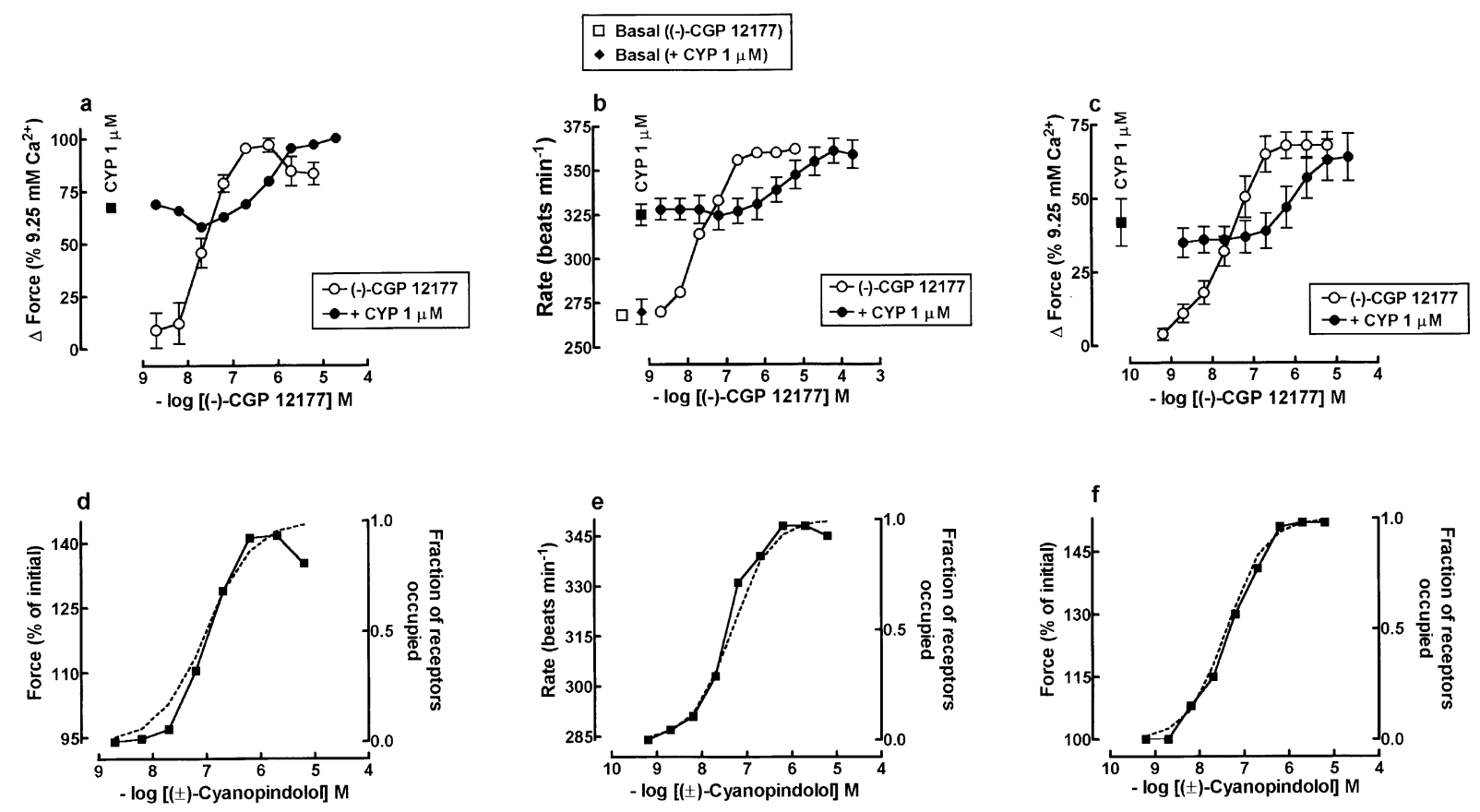

Figure 6 Antagonism of the cardiostimulant effects of (-)-CGP 12177 by $( \pm$ )-cyanopindolol in paced rat left ventricular papillary muscle (a), spontaneously beating right atrium (b) and paced left atrium (c). Cumulative concentration-effect curves were established to $(-)$-CGP 12177 in the absence (open circles) or presence (closed circles) of $1 \mu \mathrm{M}( \pm)$-cyanopindolol. $( \pm)$-Cyanopindolol caused an increase in contractile force in papillary muscles and left atria and rate in right atria as shown. All experiments were carried out in the presence of $200 \mathrm{nM}(-)$-propranolol. Additionally, experiments in papillary muscle were carried out in the presence of $30 \mu \mathrm{M}$ IBMX. Cumulative concentration-effect curves to $( \pm)$-cyanopindolol are shown in ( $\mathrm{d}-\mathrm{f}$, solid line) in left ventricular papillary muscle (d, present study) and in right atrium (e) and left atrium (f) (data from Kaumann \& Molenaar, 1996). Dotted lines show the fractional receptor occupancy calculated using the affinity $\left(\mathrm{pK}_{\mathrm{P}}\right)$ estimated for $( \pm)$-cyanopindolol from experiments shown in $(\mathrm{a}-\mathrm{c})$. Note that the concentration-effect curves and fractional occupancy curves for $( \pm)$-cyanopindolol were nearly superimposable. Shown are mean data from 2-6 individual experiments. In (a) and (c), agonist effects were expressed as a percentage of the effect caused by $9.25 \mathrm{~mm} \mathrm{Ca}^{2+}$. Vertical lines show s.e.mean. 
tility and ventricular and atrial myocyte $\mathrm{Ca}^{2+}$ studies for the existence and function of the putative $\beta_{4}$-adrenoceptor.

\section{(-)- $\left[{ }^{3} H\right]-C G P 12177$ labels the putative $\beta_{4}$-adrenoceptor in rat ventricle}

Our results with $(-)-\left[{ }^{3} \mathrm{H}\right]-\mathrm{CGP} 12177$ are consistent with labelling a ventricular population of putative $\beta_{4}$-adrenoceptors that has higher density than the combined populations of $\beta_{1^{-}}$ and $\beta_{2}$-adrenoceptors. The affinity of $(-)$-[ $\left[{ }^{3} \mathrm{H}\right]$-CGP 12177 was approximately 100 times lower for the putative $\beta_{4}$-adrenoceptor than for the $\beta_{1}, \beta_{2}$-adrenoceptors and was relatively resistant to $(-)$-propranolol. These characteristics, taken together, greatly resemble those of the putative $\beta_{4}$-adrenoceptor population of rat atrium (Sarsero et al., 1998).

\section{( \pm )-Cyanopindolol causes positive inotropic effects through a receptor that resembles a binding site with putative $\beta_{4}$-adrenoceptor characteristics}

Competition experiments between (-)-[ $\left[{ }^{3} \mathrm{H}\right]-\mathrm{CGP} 12177$ and $( \pm)$-cyanopindolol revealed three populations of binding sites: (i) a population with high affinity for $( \pm)$-cyanopindolol $\left(\mathrm{pK}_{\mathrm{i}}\right.$ 10.0) corresponding to $\beta_{1}, \beta_{2}$-adrenoceptors; (ii) a population with moderate affinity $\left(\mathrm{pK}_{\mathrm{i}} 7.4\right.$ corresponding to $\left.\beta_{4 \mathrm{H}}\right)$; and (iii) a population with low affinity $\left(\mathrm{pK}_{\mathrm{i}} 5.0\right.$ corresponding to $\left.\beta_{4 \mathrm{~L}}\right)$. Binding was unaffected by the presence or absence of GTP. To determine whether the $\beta_{4 \mathrm{H}^{-}}$or $\beta_{4 \mathrm{~L}}$-population mediated the cardiostimulant effects of $( \pm)$-cyanopindolol we devised an experiment in which the ability of $( \pm)$-cyanopindolol to block the cardiostimulant effects of (-)-CGP 12177 was assessed. These experiments relied on the observation that $( \pm)$ cyanopindolol was a partial agonist with respect to (-)-CGP 12177. In right atrium, left atrium and left ventricular papillary muscle, the cardiostimulant effects of (-)-CGP 12177 were competitively blocked by $( \pm)$-cyanopindolol with $\mathrm{pK}_{\mathrm{P}}$ of $7.0-$ 7.4. The close agreement of the binding constant of $( \pm)$ cyanopindolol $\left(\mathrm{pK}_{\mathrm{i}} 7.4 \beta_{4 \mathrm{H}}\right)$ with the estimated $\mathrm{pK}_{\mathrm{P}}$ values, estimated from surmountable blockade, are consistent with the hypothesis that $( \pm)$-cyanopindolol and (-)-CGP 12177 cause cardiostimulant effects through the high affinity state (i.e. $\beta_{4 \mathrm{H}}$ ) of the putative $\beta_{4}$-adrenoceptor. This is also illustrated by the superimposable curves of fractional receptor occupancy, calculated with the corresponding $\mathrm{pK}_{\mathrm{P}}$ values, and cardiostimulant effects of $( \pm)$-cyanopindolol. The role of the low affinity $\beta_{4 \mathrm{~L}}$ population is unclear. The sum of $\beta_{4 \mathrm{H}}$ and $\beta_{4 \mathrm{~L}}$ populations appears to add up to the $\mathrm{B}_{\max }$ of the saturation binding of $(-)-\left[{ }^{3} \mathrm{H}\right]-\mathrm{CGP} 12177$, suggesting two different states of the same receptor. Alternatively, the $\beta_{4 \mathrm{~L}}$ population could correspond to a protein labelled by $(-)-\left[{ }^{3} \mathrm{H}\right]-\mathrm{CGP} 12177$ but disintct from the receptor that mediates the cardiostimulant effects of (-)-CGP 12177 and ( \pm )-cyanopindolol.

\section{Three binding populations for $( \pm)$-cyanopindolol,} $(-)$-pindolol and $( \pm)$-carazolol in rat atrium

We reanalysed binding data obtained by Sarsero et al. (1998) in rat atrium with $( \pm)$-cyanopindolol, $(-)$-pindolol and the pindolol derivative $( \pm)$-carazolol which also revealed three

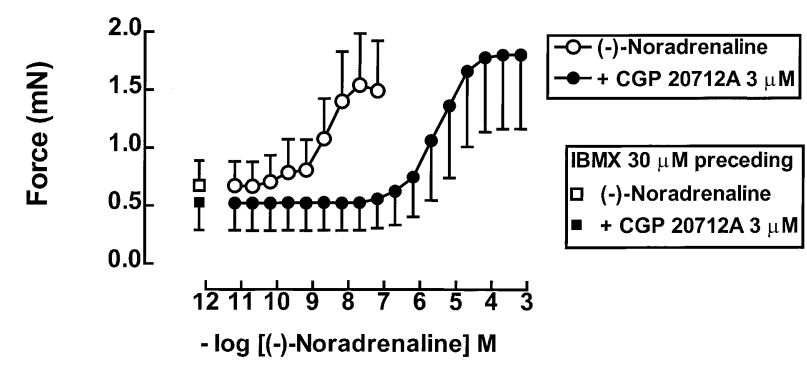

Figure 8 Blockade of cardiostimulant effects of $(-)$-noradrenaline by $3 \mu \mathrm{M}$ CGP $20712 \mathrm{~A}$ on paced rat left ventricular papillary muscle. Tissues were pre-incubated with $50 \mathrm{~nm}$ ICI 118,551 and $1 \mu \mathrm{m}$ phentolamine to block $\beta_{2^{-}}$and $\alpha$-adrenoceptors and $30 \mu \mathrm{M}$ IBMX. Values are from six and seven individual ventricular papillary muscles for (-)-noradrenaline in the absence or presence of CGP 20712A respectively. Vertical lines show s.e.mean.
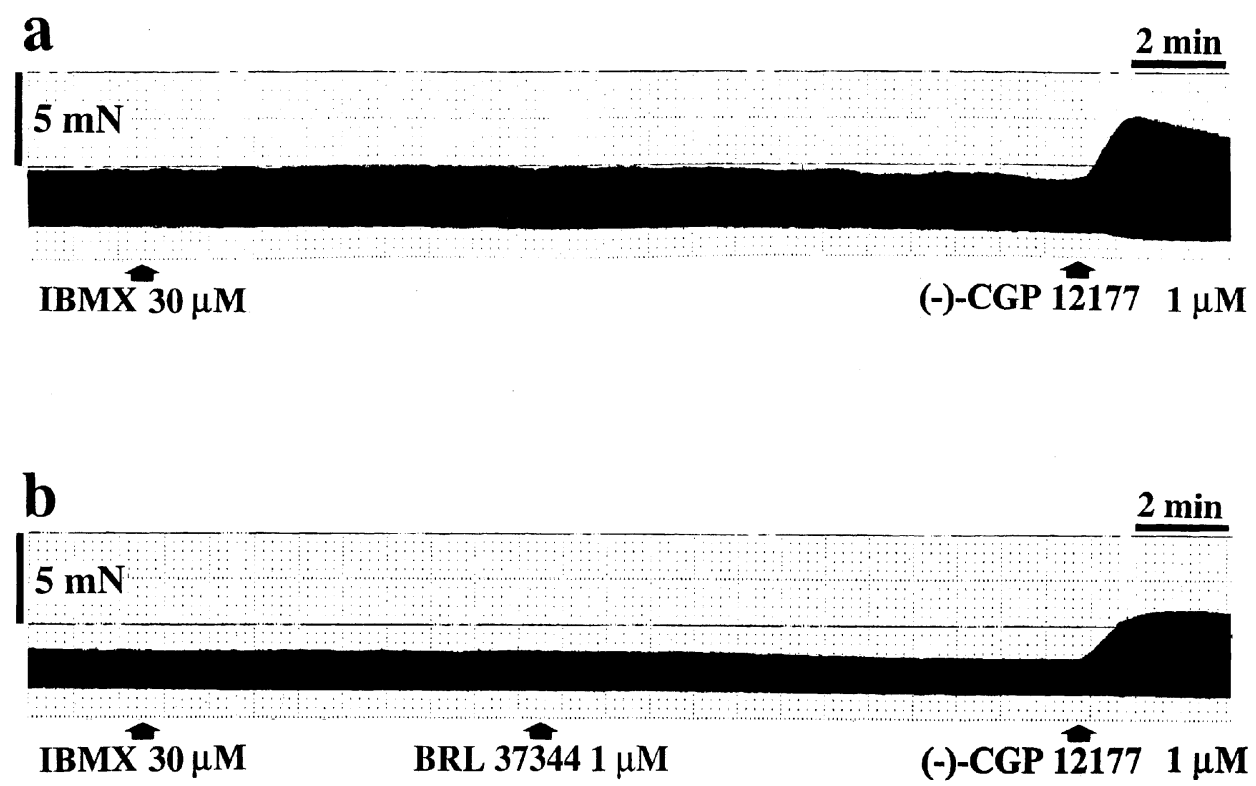

Figure 7 Lack of effect of the $\beta_{3}$-adrenoceptor agonist BRL 37344 on paced rat left ventricular papillary muscle. Shown are two time-matched left ventricular papillary muscles incubated with $30 \mu \mathrm{M}$ IBMX. In (b) but not (a) $1 \mu \mathrm{M}$ BRL 37344 was added which had no effect on contractile force, nor did it have any effect on the positive inotropic effect of $1 \mu \mathrm{M}(-)$-CGP 12177 . 
receptor populations. Interestingly, however, the proportion of the low affinity form $\left(\beta_{4 \mathrm{~L}}\right)$ varied from $5 \%$ of total $(( \pm)$ carazolol), $14 \%$ ((-)-pindolol) to $25 \%(( \pm)$-cyanopindolol). As in ventricle, the significance of the low affinity form is not clear at this time, but does not appear to be related, at least functionally, to $\beta_{1^{-}}, \beta_{2^{-}}$or putative $\beta_{4}$-adrenoceptors in rat heart. However, it is possible that the low affinity population is a conformation of the putative $\beta_{4}$-adrenoceptor $\left(\beta_{4 \mathrm{~L}}\right)$ stabilized as a function of agonist chemistry. This possibility is supported by the fact that the maximal density of binding $\left(\mathrm{B}_{\max }\right)$ of the putative $\beta_{4}$-adrenoceptors is only matched by the sum of the percentage densities of the low and intermediate affinity populations (i.e. $\beta_{4 \mathrm{H}}+\beta_{4 \mathrm{~L}}=\beta_{4}$ ). Alternatively, as argued for the ventricle, the atrial $\beta_{4 \mathrm{~L}}$ population may be distinct from the receptor that mediates cardiostimulation.

IBMX reveals positive inotropic and lusitropic effects of (-)-CGP 12177 and ( \pm )-cyanopindolol in left ventricular papillary muscle

(-)-CGP 12177 does not increase contractility in left ventricular papillary muscle of rat in the absence of IBMX (Kaumann \& Molenaar, 1996). We previously showed that the

Table 6 Effects of (-)-CGP 12177 and (-)-isoprenaline on $\mathrm{Ca}^{2+}$ fluorescence transients in rat ventricular myocytes

\begin{tabular}{|c|c|c|c|c|c|c|c|c|}
\hline Experimental condition & $\mathrm{n}^{*}$ & $\begin{array}{l}\% \text { increase in } \\
\text { fluorescence } \\
\text { amplitude }\end{array}$ & $\mathrm{P}^{* *}$ & $t_{50} \neq$ & $\mathrm{P}^{* *}$ & $\begin{array}{c}\text { Late } \\
\text { after } \\
\text { transient } t+\end{array}$ & $\begin{array}{c}\text { Arrhythmias } \\
\text { Early } \\
\text { after } \\
\text { transient: }\end{array}$ & $\begin{array}{c}\text { Non- } \\
\text { arrhythmic } \\
\text { cellst+ }\end{array}$ \\
\hline $1 \mu \mathrm{M}(-)-\mathrm{CGP} 12177$ & $5(3)$ & $16.8 \pm 6.2$ & 0.05 & $\begin{array}{c}\text { B } 287 \pm 33 \\
247 \pm 25\end{array}$ & 0.36 & 0 & 1 & 4 \\
\hline $1 \mu \mathrm{M}(-)$-CGP $12177+1 \mu \mathrm{M}$ IBMX & $5(3)$ & $92.5 \pm 24.3$ & 0.01 & $\begin{array}{c}\text { B } 246 \pm 19 \\
159 \pm 21\end{array}$ & 0.02 & 2 & 1 & 3 \\
\hline $\begin{array}{l}10 \mathrm{nM}(-) \text {-CGP } 12177+1 \mu \mathrm{M} \text { IBMX }+ \\
200 \mathrm{nM}(-) \text {-propranolol }\end{array}$ & $7(3)$ & $47.9 \pm 14.2$ & 0.06 & $\begin{array}{l}\text { B } 330 \pm 19 \\
321 \pm 17\end{array}$ & 0.73 & 3 & 1 & 3 \\
\hline $\begin{array}{l}100 \mathrm{nM}(-) \text {-CGP } 12177+1 \mu \mathrm{M} \text { IBMX }+ \\
200 \mathrm{nM}(-) \text {-propranolol }\end{array}$ & $12(6)$ & $25.1 \pm 8.7$ & 0.009 & $\begin{array}{c}\text { B } 346 \pm 41 \\
291 \pm 33\end{array}$ & 0.31 & 7 & 5 & 4 \\
\hline $\begin{array}{l}1 \mu \mathrm{M}(-) \text {-CGP } 12177+1 \mu \mathrm{M} \text { IBMX }+ \\
200 \mathrm{nM}(-) \text {-propranolol }\end{array}$ & $7(3)$ & $72.6 \pm 20.1$ & 0.004 & $\begin{array}{c}\text { B } 294 \pm 31 \\
150 \pm 7\end{array}$ & 0.0007 & 2 & 1 & 5 \\
\hline $100 \mathrm{~nm}(-)$-Isoprenaline & $13(6)$ & $62.3 \pm 12.7$ & 0.003 & $\begin{array}{c}\text { B } 230 \pm 16 \\
136 \pm 8\end{array}$ & 0.0001 & 10 & 8 & 1 \\
\hline
\end{tabular}

* $n$ values are numbers of cells from $n$ hearts between parentheses. $* * P$ value compared to 0 ( $\%$ increase in fluorescence amplitude) or basal value $\left(\mathrm{t}_{50}\right)$. $\$$ Time $(\mathrm{ms})$ to reach $50 \%$ decrease in $\mathrm{Ca}^{2+}$ fluorescence transients, $\mathrm{B}$ is basal value prior to incubation with drug. $\$$ Number of cells. Arrhythmias were observed after measurements of increase in $\mathrm{Ca}^{2+}$ transient amplitude and \% reduction in $\mathrm{t}_{50}$ were taken.

$\mathbf{a}$



b

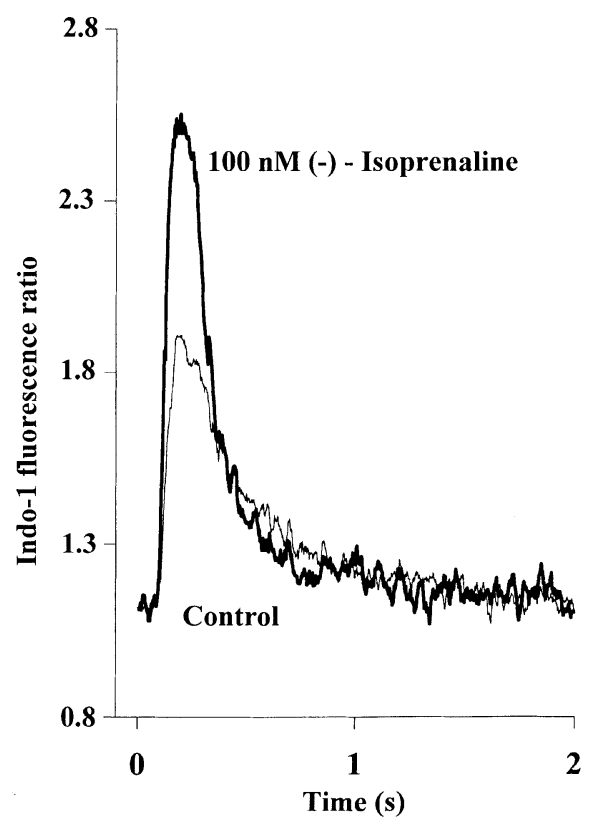

Figure 9 Representative original traces showing the enhancement of $\mathrm{Ca}^{2+}$ transients by $(-)$-CGP 12177 and $(-)$-isoprenaline in atrial myocytes. (-)-CGP $12177(1 \mu \mathrm{M})$ in the presence of $200 \mathrm{nM}(-)$-propranolol and $100 \mathrm{nM}(-)$-isoprenaline in the absence of $(-)$-propranolol caused increases in $\mathrm{Ca}^{2+}$ transients. 

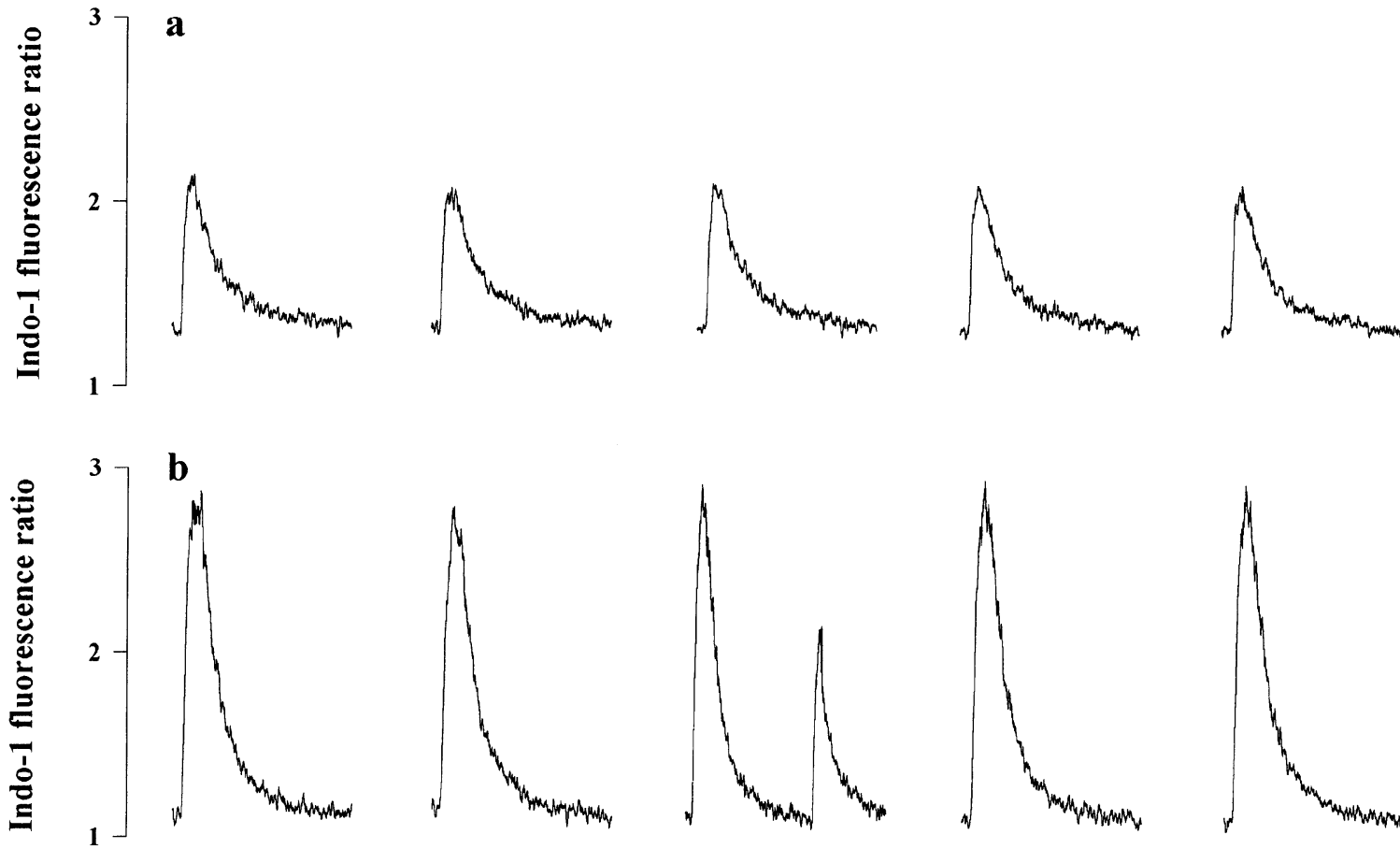

Extrasystole

Figure 10 Representative traces showing a late arrhythmic $\mathrm{Ca}^{2+}$ aftertransient caused by (-)-CGP 12177 in an atrial myocyte Top panels show five consecutive control $\mathrm{Ca}^{2+}$ transients in the presence of $200 \mathrm{nM}(-)$-propranolol. Bottom panels show five consecutive $\mathrm{Ca}^{2+}$ transients in the presence of $1 \mu \mathrm{M}(-)$-CGP 12177 and $200 \mathrm{nM}(-)$-propranolol which caused an increase in the amplitude and hastened the decline of the $\mathrm{Ca}^{2+}$ transients and caused a late aftertransient (extrasystole).

$\mathbf{a}$

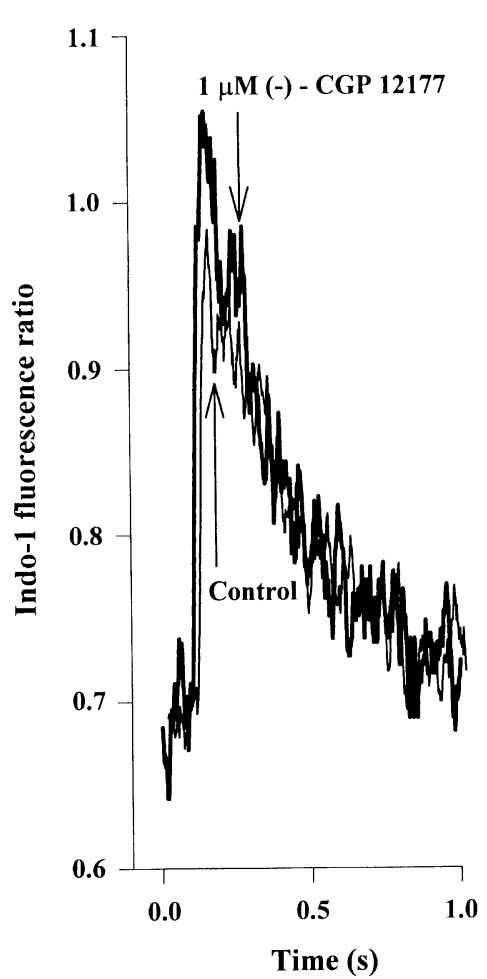

b

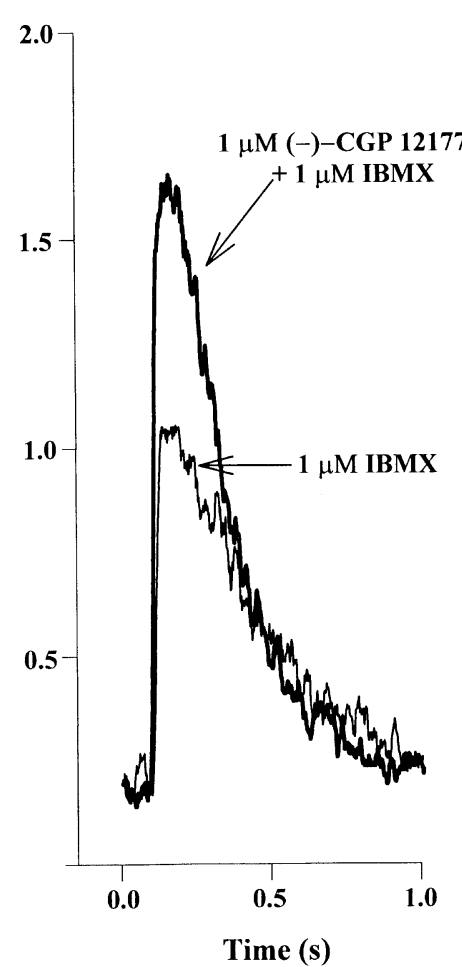

c

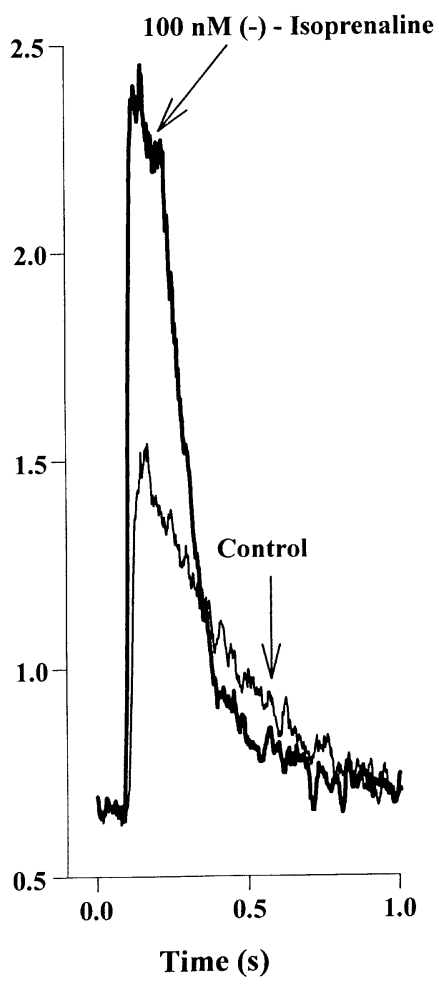

Figure 11 Representative original traces showing the enhancement of $\mathrm{Ca}^{2+}$ transients by (-)-CGP $12177+\mathrm{IBMX}$ in rat ventricular myocytes: comparison with (-)-isoprenaline. (-)-CGP $12177(1 \mu \mathrm{M})$ only caused a small increase in the $\mathrm{Ca}^{2+}$ transient compared to control (a). In the presence of $1 \mu \mathrm{M}$ IBMX, $1 \mu \mathrm{M}(-)$-CGP 12177 caused an increase and hastened the decline of the $\mathrm{Ca}^{2+}$ transient compared to IBMX alone (b). (-)-Isoprenaline $(100 \mathrm{nM})$ caused an enhancement and hastened decline of the Ca ${ }^{2+}$ transient in the absence of IBMX (c). 
cardiostimulant effects of (-)-CGP 12177 in rat right and left atrium were potentiated by the phosphodiesterase inhibitor IBMX (Kaumann \& Lynham, 1997). On this basis we investigated the presence of a functional putative $\beta_{4^{-}}$ adrenoceptor in rat ventricle. In the presence of IBMX, both (-)-CGP 12177 and ( \pm )-cyanopindolol increased contractile force in rat left ventricular papillary muscles. In addition, (-)CGP 12177 caused positive lusitropic effects. In rat right and left atrium, cardiostimulant effects of (-)-CGP 12177 and $( \pm)$-cyanopindolol can be observed in the absence of IBMX (Kaumann \& Molenaar, 1996). Given the similar density of putative $\beta_{4}$-adrenoceptors in atrium (Sarsero et al., 1998) and ventricle, it would seem that putative $\beta_{4}$-adrenoceptors are less well coupled to $G_{\mathrm{s}}$ protein in ventricle compared to atrium and that phosphodiesterase hydrolizes more cyclic AMP, elevated through $\beta_{4}$-adrenoceptor stimulation in ventricle than in atrium. However, when phosphodiesterases are apparently inhibited by IBMX, the putative $\beta_{4}$-adrenoceptor not only mediates increases in contractile force but also in the rate of relaxation (Figure 5b) as expected from a cyclic AMP pathway. In addition, putative $\beta_{4}$-adrenoceptors may also couple to a cyclic AMP inhibitory G-protein. The smaller effect of putative $\beta_{4}$-adrenoceptor agonists in ventricle could then be explained by more efficient coupling to ventricular inhibitory G-proteins. When phosphodiesterases are inhibited by IBMX, the $\mathrm{G}_{\mathrm{s}}$ protein-cyclic AMP pathway is preferred. The effects of (-)-CGP 12177 in ventricle are species dependent. Whilst IBMX is required to reveal positive inotropic effects in rat and human ventricle (Kaumann \& Molenaar, 1997; Molenaar et al., 1997) this is not the case in ferret left and right ventricle where (-)-CGP 12177 mediates robust positive inotropic effects in the absence of phosphodiesterase inhibition (Lowe et al., 1999).

The effects of ( - )-CGP 12177 and ( \pm )-cyanopindolol were competitively blocked by (-)-bupranolol $\left(\mathrm{pK}_{\mathrm{B}} 6.7-7.0\right)$ and
CGP 20712A ( $\mathrm{pK}_{\mathrm{B}}$ 6.3-6.6). The similarity of $\mathrm{pK}_{\mathrm{B}}$ values for (-)-bupranolol and CGP 20712A obtained with each agonist is consistent with the idea that both stimulate the same receptor. The affinity values $\left(\mathrm{pK}_{\mathrm{B}}\right)$ for $(-)$-bupranolol are similar to values obtained previously at the putative $\beta_{4^{-}}$ adrenoceptor in rat atrium (6.4-6.8, Kaumann \& Molenaar, 1996).

\section{No evidence for ventricular $\beta_{3}$-adrenoceptors}

It has previously been argued that the $\beta_{3}$-adrenoceptor mediates negative inotropic effects in human ventricle by agonists such as BRL 37344 (Gauthier et al., 1996) through release of nitric oxide (Gauthier et al., 1998). It has also been reported preliminarily that BRL 37344 decreases $\mathrm{Ca}^{2+}$ transients and contractility of canine myocytes (Cheng et al., 1998). We also tested BRL 37344 in the presence of $200 \mathrm{nM}(-)$-propranolol in rat ventricular papillary muscle and showed that it had no effect on its own nor did it have any effect on the positive inotropic response of (-)-CGP 12177. This is consistent with experiments in rat right and left atrium in which it was shown that the $\beta_{3}$-adrenoceptor agonists, BRL 37344, CL 316243, ZD 2079 and SR 58611A had no effect (Kaumann \& Molenaar, 1996). The absence of a cardiac $\beta_{3}$-adrenoceptor which modulates contractile force agrees with other studies in which it was shown that the four $\beta_{3}$-adrenoceptor agonists had no effect on contractile force in human right ventricular trabeculae (Kaumann \& Molenaar, 1997; Molenaar et al., 1997), ICI 215,001 which did not cause a negative inotropic effect in human ventricular myocytes (Harding, 1997) and lack of effect of CL 316243 and (-)-isoprenaline on spontaneously beating right atria or paced right ventricular strips of $\beta_{1-1}$ $\beta_{2}$-adrenoceptor double knockout mice (Rohrer et al., 1999). Gauthier et al. (1996) also observed $\beta_{3}$-adrenoceptor

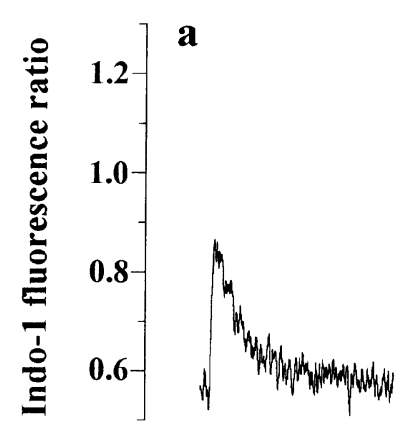

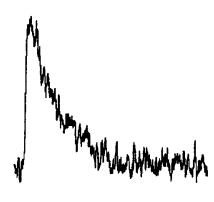

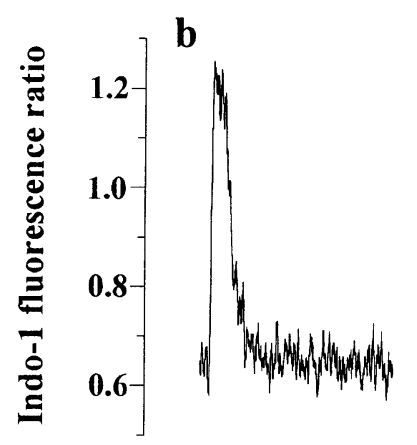

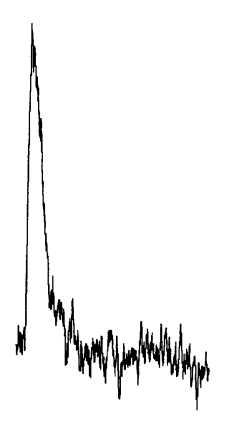
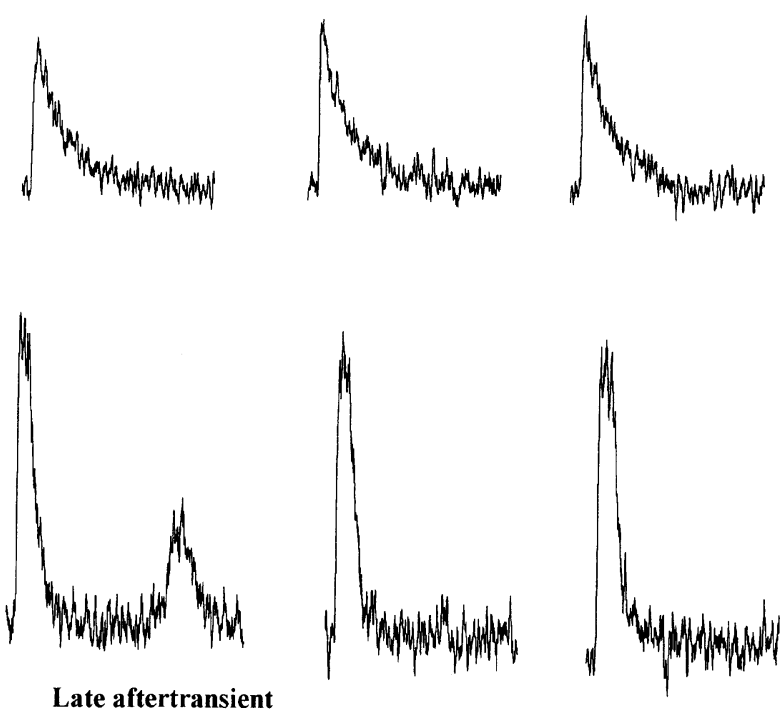

Figure 12 Representative traces showing a late slow aftertransient caused by (-)-CGP 12177 in a ventricular myocyte. Top panels show five consecutive control calcium transients in the presence of $1 \mu \mathrm{M}$ IBMX and $200 \mathrm{nM}(-)$-propranolol. Bottom panels show five consecutive $\mathrm{Ca}^{2+}$ transients in the presence of $1 \mu \mathrm{M}(-)$-CGP 12177, $1 \mu \mathrm{M}$ IBMX and 200 nM (-)-propranolol which caused an increase in amplitude and hastened the decline of the $\mathrm{Ca}^{2+}$ transients, and the slow aftertransient. 
mediated reductions in the duration of human ventricular action potentials with BRL 37344 and SR 58611, measured at 30, 50 and $90 \%$ repolarization. Lowe et al. (1998) reported that (-)-CGP 12177 caused reductions in ventricular action potential duration in ferret heart at 90 , 70 and $50 \%$ repolarization, consistent with an increase in $\mathrm{K}^{+}$channel permeability, but prolongation at $10 \%$ repolarization, consistent with activation of L-type $\mathrm{Ca}^{2+}$ channels. The effects of (-)-CGP 12177 were interpreted as being due to stimulation of the putative $\beta_{4}$-adrenoceptor. In the same study, they did not observe changes of action potential duration or left ventricular developed pressure in ferret heart with the selective $\beta_{3}$-adrenoceptor agonists BRL 37344 or CL 316243.

\section{The cardiostimulant effects of (-)-noradrenaline are mediated by stimulation of $\beta_{1}$-adrenoceptors in left ventricular papillary muscle}

Under the conditions used to reveal the cardiostimulant effects of (-)-CGP 12177 and ( \pm )-cyanopindolol in left ventricular papillary muscle (in the presence of IBMX), $3 \mu \mathrm{M}$ CGP 20712A caused greater blockade of the positive inotropic effects of $(-)$-noradrenaline $(3.3 \mathrm{log}$ unit shift) than either (-)-CGP $12177 \quad(1.1 \quad \log$ unit) or $( \pm)$ cyanopindolol (0.7 log unit). The high blocking potency of CGP 20712A against the effects of $(-)$-noradrenaline can be accounted for by an interaction solely with $\beta_{1}$-adrenoceptors, consistent with previous observations (Kaumann, 1986; Kaumann \& Molenaar, 1996).

\section{Abbreviated $\mathrm{Ca}^{2+}$ transients in atrial compared to ventricular myocytes}

It is well known that atrial muscle relaxes faster than ventricular muscle and correspondingly $\mathrm{Ca}^{2+}$ transients are shorter in atrial myocytes than in ventricular myocytes. The difference between the duration of atrial and ventricular contractions and $\mathrm{Ca}^{2+}$ transients is due, at least in part, to a greater phospholamban expression and activity in ventricle than in atrium (Koss et al., 1995; Moorman et al., 1995). Unphosphorylated phospholamban blunts the activity of the $\mathrm{Ca}^{2+}$ pump of the sarcoplasmic reticulum, thereby impeding $\mathrm{Ca}^{2+}$ uptake and slowing relaxation more in ventricular than atrial myocytes.

IBMX is required to reveal (-)-CGP 12177-evoked increases in $\mathrm{Ca}^{2+}$ transients in ventricular myocytes but not atrial myocytes

(-)-CGP 12177 caused potent increases in $\mathrm{Ca}^{2+}$ transients in rat atrial myocytes which were observed in the absence of IBMX and were unaffected by the presence of $200 \mathrm{nM}(-)$ propranolol. Previously we showed that (-)-CGP 12177 also increases contractile force in left atria under these conditions (Kaumann \& Molenaar, 1996; Kaumann \& Lynham, 1997). (-)-CGP 12177 had little effect on the transients in rat ventricular myocytes in the absence of stimulation with IBMX. However, $\mathrm{Ca}^{2+}$ transients were augmented by (-)-CGP 12177 in the presence of IBMX. This is also consistent with functional studies in isolated left ventricular papillary muscles in which it appears that (-)-CGP 12177 in the absence of IBMX fails to generate sufficient cytosolic $\mathrm{Ca}^{2+}$ to cause an increase in contractile force. As argued for contractility data in atrial and ventricular tissues, the $\mathrm{Ca}^{2+}$ transient data are consistent with the hypotheses that the putative $\beta_{4}$-adreno- ceptor is coupled less efficiently to the $G_{s} /$ adenylyl cyclase pathway in ventricular myocytes compared to atrial myocytes and/or putative $\beta_{4}$-adrenoceptor mediated increases in cyclic AMP are more efficiently hydrolyzed in ventricle than atrium.

\section{(-)-CGP 12177 mediates hastened decline of the ventricular $\mathrm{Ca}^{2+}$ transient}

Consistent with hastening of relaxation of papillary muscles (Figure 5b) (-)-CGP 12177 (in the presence of IBMX) also shortened the duration of ventricular $\mathrm{Ca}^{2+}$ transients. These results are probably due to the phosphorylation of phospholamban catalysed by cyclic AMP-dependent protein kinase (PKA), thereby disinhibiting the $\mathrm{Ca}^{2+}$ pump of the sarcoplasmic reticulum and accelerating re-uptake of $\mathrm{Ca}^{2+}$ by the sarcoplasmic reticulum, thus hastening relaxation (Koss \& Kranias, 1996; Calaghan et al., 1998). In addition, troponin I may also contribute to relaxation through phosphorylation by PKA by decreasing the $\mathrm{Ca}^{2+}$ sensitivity of contractile proteins (Robertson et al., 1982; Zhang et al., 1995). However, PKAevoked phosphorylation of both phospholamban and troponin I through activation of putative $\beta_{4}$-adrenoceptors still requires biochemical verification.

In both human atrial and ventricular myocardium, stimulation of $\beta_{1}, \beta_{2^{-}}$or putative $\beta_{4}$-adrenoceptors, also causes hastening of relaxation, possibly through a common mechanism involving phosphorylation of phospholamban and troponin I (Kaumann et al., 1996; 1999; Kaumann \& Molenaar, 1997).

In rat ventricular myocytes, simulation of $\beta_{1}$-adrenoceptors also causes an abbreviation of the $\mathrm{Ca}^{2+}$ transient time (Xiao \& Lakatta, 1993). Stimulation of $\beta_{2}$-adrenoceptors also hastens $\mathrm{Ca}^{2+}$ transients in neonatal ventricular myocytes (Kuznetsov et al., 1995) but not myocytes from adult rats unless myocytes have been incubated with pertussis toxin to block $G_{i} / G_{o}$ protein (Xiao et al., 1995). In the latter case it is thought that $\beta_{2}$-adrenoceptors simultaneously couple to both cyclic AMP inhibitory and stimulatory pathways.

On the other hand, although (-)-CGP 12177 enhanced the amplitude of atrial $\mathrm{Ca}^{2+}$ transients it only reduced their duration inconsistently and without significance (Figure 9, small effect on $t_{50}$, Figure 10 marked reduction of $t_{50}$ ) and when it did, it was usually to a smaller extent that in ventricular myocytes (compare Tables 5 and 6). These differences could in part be due to higher levels of phospholamban in ventricular than atrial myocytes and therefore more inhibition of the ventricular pumping rate of the sarcoplasmic reticulum ATPase (Koss et al., 1995). Consistent with this interpretation, the $\mathrm{Ca}^{2+}$ transientabbreviating effect of (-)-isoprenaline was greater in ventricular than atrial myocytes (Tables 5 and 6).

\section{Arrhythmias mediated through the putative $\beta_{4}$-adrenoceptor}

Arrhythmic $\mathrm{Ca}^{2+}$ transients mediated through the putative $\beta_{4}$ adrenoceptor were observed in rat atrial and ventricular myocytes. (-)-CGP 12177 caused early and late aftertransients and the latter were fast (Figure 10) or slow (Figure 12). The late fast aftertransients have fast upstrokes (rate of rise) and are probably due to generation of a new action potential. On the other hand, the late slow aftertransients with slow rate of rise are probably due to increases of intramyocyte $\mathrm{Ca}^{2+}$ without formation of a new action potential. (-)Isoprenaline also caused arrhythmic transients in several cells, presumably through $\beta_{1}$-adrenoceptors. 
Arrhythmic $\mathrm{Ca}^{2+}$ transients in atrial myocytes appeared to depend on the (-)-CGP 12177 concentration and to correlate directly with the global $\mathrm{Ca}^{2+}$ increase. On the other hand, arrhythmic $\mathrm{Ca}^{2+}$ transients in ventricular myocytes did not depend on (-)-CGP 12177 concentration, presumably because the potentiating effect of IBMX (Kaumann \& Lynham , 1997) facilitated maximum effects at the lowest (-)-CGP 12177 concentration used. In addition, for unknown reasons there was also a trend for a reduction in the incidence of arrhythmias at the highest (-)-CGP 12177 concentration used $(1 \mu \mathrm{M})$, despite further increase in global myocyte $\mathrm{Ca}^{2+}$. Both (-)-CGP 12177 and (-)-isoprenaline caused concentration-dependent arrhythmic $\mathrm{Ca}^{2+}$ transients in the absence of IBMX in mouse ventricular myocytes and interestingly (-)-CGP 12177 was 40 times more potent than (-)-isoprenaline (Freestone et al., 1999). These observations demonstrate that (-)-CGP 12177 can elicit concentration-dependent ventricular arrhythmias, presumably due to a lower cyclic AMP hydrolysis by phosphodiesterase in mouse myocytes compared to rat myocytes.

Ventricular arrhythmias, mediated through stimulation of the $\beta_{1}$-adrenoceptor and the putative $\beta_{4}$-adrenoceptor have previously been observed in intact ferret heart (Lowe et al., 1998). Stimulation of $\beta_{1}$-adrenoceptors but not of putative $\beta_{4^{-}}$ adrenoceptors caused a significant reduction in the ventricular refractory period and therefore it was suggested that $\beta_{1}$ - and putative $\beta_{4}$-adrenoceptors may mediate arrhythmias by different mechanisms.

\section{Are the effects of (-)-CGP 12177 mediated by stimulation of $\beta_{1}$-adrenoceptors?}

In this and previous reports (Kaumann, 1989; 1996; 1997; Kaumann et al., 1998; Kaumann \& Molenaar, 1996; Molenaar et al., 1997; Lowe et al., 1998; 1999) we interpreted the effects of (-)-CGP 12177 as being caused by activation of the putative $\beta_{4}$-adrenoceptor. In cardiac muscle, stimulant effects are observed to a series of compounds described as nonconventional partial agonists which include (-)-CGP 12177 and cyanopindolol (Kaumann, 1989). Non-conventional partial agonists cause blockade of responses mediated by stimulation of $\beta_{1}, \beta_{2}$-adrenoceptors but at higher concentrations cause stimulant effects which are relatively resistant to blockade by antagonists such as (-)-propranolol, but can be blocked with moderate affinity by $(-)$-bupranolol. In this respect the pharmacology of the putative $\beta_{4}$-adrenoceptor is similar to the $\beta_{3}$-adrenoceptor, however, the receptors are distinct because putative $\beta_{4}$-adrenoceptor function and densities are preserved in mouse heart with targeted disruption of the $\beta_{3}$-adrenoceptor gene (Kaumann et al., 1998).

The dissociation of antagonist (high affinity) and agonist (low potency) properties of (-)-CGP 12177 was also observed at recombinant human and rat $\beta_{1}$-adrenoceptors expressed at high densities in several cell lines (Pak \& Fishman, 1996). A high concentration, $(10 \mu \mathrm{M})$, of (-)-CGP 12177 caused an increase in cyclic AMP accumulation with intrinsic activity values ranging from $0.21-0.94$ relative to $(-)$-isoprenaline, corresponding to $\beta_{1}$-adrenoceptor densities of $130-$ $1570 \mathrm{fmol} \mathrm{mg}^{-1}$ protein. These effects were attributed to stimulation of a guanine nucleotide sensitive form of the $\beta_{1}$ adrenoceptor, coupled to $\mathrm{G}_{\mathrm{s}}$ protein, which comprised approximately $10 \%$ of the total population of $\beta_{1}$-adrenoceptors (Pak \& Fishman, 1996) and it has been argued that the putative $\beta_{4}$-adrenoceptor could correspond to a low affinity state of the $\beta_{1}$-adrenoceptor (Lowe et al., 1999).

It is not clear, however, whether the putative $\beta_{4^{-}}$ adrenoceptor is a low affinity state of the $\beta_{1}$-adrenoceptor because some inconsistencies exist and require clarification. In this study we have labelled the rat ventricular putative $\beta_{4}$ adrenoceptor and showed it exists in higher densities compared to $\beta_{1}$-adrenoceptors. Rat atrium also has higher densities of putative $\beta_{4}$-adrenoceptors than $\beta_{1}$-adrenoceptors (Sarsero et al., 1998) which is unlike the low affinity component of the $\beta_{1^{-}}$adrenoceptor population reported by Pak \& Fishman (1996), which exists as a smaller proportion $(10 \%)$ of the total $\beta_{1}$ adrenoceptor population. In rat atrium (Sarsero et al., 1998) we also showed that the putative $\beta_{4}$-adrenoceptor binding site is insensitive to guanine nucleotides unlike the low affinity component of the recombinant and transfected $\beta_{1}$-adrenoceptor (Pak \& Fishman, 1996).

If the low affinity component of the $\beta_{1}$-adrenoceptor identified by Pak \& Fishman (1996), which is responsible for the agonist properties of (-)-CGP 12177, is the same as the putative $\beta_{4}$-adrenoceptor, then it would have implications in terms of receptor theory and the basis upon which receptors have been classified in the past. The presence of a high affinity state of either the $\beta_{1}$ - or putative $\beta_{4}$-adrenoceptor should also be considered because in mouse ventricular myocytes (-)-CGP 12177 is 40 times more potent than (-)-isoprenaline in eliciting arrhythmias (Freestone et al., 1999). At the present time it is not yet possible to uniquely define and estimate experimentally an equilibrium dissociation constant for a distinct state.

\section{Conclusions}

Similar densities of putative $\beta_{4}$-adrenoceptors exist in rat atrium and ventricle, however, unlike rat atrium, cardiostimulant effects of (-)-CGP 12177 are only apparent in rat ventricle in the presence of IBMX when phosphodiesterases are presumably inhibited. Under these conditions, stimulation of the putative $\beta_{4}$-adrenoceptor mediates increases in contractile force, amplitude of $\mathrm{Ca}^{2+}$ transients and hastening of both relaxation and the decline of $\mathrm{Ca}^{2+}$ transients in rat ventricle. The putative $\beta_{4}$-adrenoceptor appears more tightly coupled to the $\mathrm{G}_{\mathrm{s}}$-adenylyl cyclase-cyclic AMP system in rat atria than ventricle and/or cyclic AMP levels increased through this receptor are more easily hydrolyzed in ventricle than in atrium.

A.J. Kaumann and N.S. Freestone are grateful to the British Heart Foundation and P. Molenaar to the NHMRC (Australia) for support.

\section{References}

BLINKS, J.R. (1965). Convenient apparatus for recording contractions of isolated muscle. J. Appl. Physiol., 20, 755-757.

CALAGHAN, S.C., WHITE, E. \& COLYER, J. (1998). Co-ordinated changes in cAMP, phosphorylated phospholamban, $\mathrm{Ca}^{2+}$ and contraction following $\beta$-adrenergic stimulation of rat heart. Pflügers Arch., 436, $948-956$.

CHENG, H.-J., ONISHI, K., ZHANG, Z.-S., LITTLE, W.S., SANE, D.S. \& CHENG, C.-P. (1998). Functional $\beta_{3}$-adrenergic receptors in the canine myocardium. Circulation (abstract), 98, I-125.

CHENG, Y. \& PRUSSOFF, W.H. (1973). Relationship between the inhibition constant $\left(\mathrm{K}_{1}\right)$ and the concentration of inhibitor which causes 50 percent inhibition $\left(\mathrm{I}_{50}\right)$ of an enzymatic reaction. Biochem. Pharmacol., 22, 3099-3108.

FREESTONE, N.S., HEUBACH, J.F., WETTWER, E., RAVENS, U., BROWN, D. \& KAUMANN, A.J. (1999). Putative $\beta_{4}$-adrenoceptors are more effective than $\beta_{1}$-adrenoceptors in mediating arrhythmic $\mathrm{Ca}^{2+}$ transients in mouse ventricular myocytes. NaunynSchmiedeberg's Arch. Pharmacol., 360, 445-446. 
FREESTONE, N. \& KAUMANN, A.J. (1997). Activation of an atypical $\beta$-adrenoceptor increases calcium and can elicit arrhythmias in rat atrial cardiomyocytes. The Pharmacologist, 39, 74 (Abstract 292).

FREESTONE, N.S., RIBARIC, S. \& MASON, W.T. (1996). The effect of insulin-like growth factor 1 on adult rat cardiac contractility. Mol. Cell. Biochem., 163/164, 223-229.

GAUTHIER, C., LEBLAIS, V., KOBZIK, L., TROCHU, J.-N., KHANDOUDI, N., BRIL, A., BALLIGAND, J.-L. \& LE MAREC, H. (1998). The negative inotropic effect of $\beta_{3}$-adrenoceptor stimulation is mediated by activation of a nitric oxide synthase pathway in human ventricle. J. Clin. Invest., 102, 1377-1384.

GAUTHIER, C., TAVERNIER, G., CHARPENTIER, F., LANGIN, D. \& LE MAREC, H. (1996). Functional $\beta_{3}$-adrenoceptor in the human heart. J. Clin. Invest., 98, 556-562.

Gille, E., LEMOINE, H., EHLE, B. \& KAUMANN, A.J. (1985). The affinity of $(-)$-propranolol for $\beta_{1^{-}}$and $\beta_{2}$-adrenoceptors of human heart. Differential antagonism of the positive inotropic effects and adenylate cyclase stimulation by $(-)$-noradrenaline and (-)-adrenaline. Naunyn-Schmiedeberg's Arch. Pharmacol. 331, $60-70$.

HARDING, S. (1997). Lack of evidence for $\beta_{3}$-adrenoceptor modulation of contractile function in human ventricular myocytes. Circulation, 96, I- 53.

HARDING, S.E., VESCOVO, G., KIRBY, M., JONES, S.M., GURDEN, J. \& POOLE-WILSON, P.A. (1988). Contractile responses of isolated rat and rabbit myocytes to isoproterenol and calcium. J. Mol. Cell. Cardiol., 20, 635-647.

KAUMANN, A.J. (1986). The $\beta_{1}$-adrenoceptor antagonist CGP 20712 A unmasks $\beta_{2}$-adrenoceptors activated by $(-)$-adrenaline in rat sinoatrial node. Naunyn-Schmiedeberg's Arch. Pharmacol., 332, $406-409$.

KAUMANN, A.J. (1989). Is there a third heart $\beta$-adrenoceptor? Trends Pharmacol. Sci., 10, 316-320.

KAUMANN, A.J. (1996). (-)-CGP 12177-induced increase of human atrial contraction through a putative third $\beta$-adrenoceptor. $\mathrm{Br}$. $J$. Pharmacol., 117, 93-98.

KAUMANN, A.J. (1997). Four $\beta$-adrenoceptor subtypes in the mammalian heart. Trends Pharmacol. Sci., 18, 70-76.

KAUMANN, A., BARTEL, S., MOLENAAR, P., SANDERS, L., BURRELL, K., VETTER, D., HEMPEL, P., KARCZEWSKI, P. \& KRAUSE, E.-G. (1999). Activation of $\beta_{2}$-adrenergic receptors hastens relaxation and mediates phosphorylation of phospholamban, troponin I, and C-protein in ventricular myocardium from patients with terminal heart failure. Circulation, 99, 65-72.

KAUMANN, A.J. \& FREESTONE, N. (1997). Atypical $\beta$-adrenoceptor activation by (-)-CGP 12177 increases cytosolic calcium in rat ventricular myocytes. The Pharmacologist, 39, 74 (Abstract 293).

KAUMANN, A.J. \& LYNHAM, J.A. (1997). (-)-CGP 12177A stimulates cyclic AMP-dependent protein kinase in rat atria through an atypical $\beta$-adrenoceptor. Br. J. Pharmacol., 120, $1187-1189$

KAUMANN, A.J., LYNHAM, J.A., SARSERO, D. \& MOLENAAR, P. (1997). The atypical cardiostimulant $\beta$-adrenoceptor is distinct from $\beta_{3}$-adrenoceptors and coupled to a cyclic AMP-dependent pathway in human and rat myocardium. Br. J. Pharmacol., 120, $102 \mathrm{P}$.

KAUMANN, A.J. \& MOLENAAR, P. (1996). Differences between the third cardiac $\beta$-adrenoceptor and the colonic $\beta_{3}$-adrenoceptor in the rat. Br. J. Pharmacol., 118, 2085-2098.

KAUMANN, A.J. \& MOLENAAR, P. (1997). Modulation of human cardiac function through $4 \beta$-adrenoceptor populations. NaunynSchmiedeberg's Arch. Pharmacol., 355, 667-681.

KAUMANN, A.J., PREITNER, F., SARSERO, D., MOLENAAR, P., REVELLI, J.-P. \& GIACOBINO, J.P. (1998). (-)-CGP 12177 causes cardiostimulation and binds to cardiac putative $\beta_{4}$-adrenoceptors in both wild-type and $\beta_{3}$-adrenoceptor knockout mice. Mol. Pharmacol., 53, 670-675.

KAUMANN, A.J., SANDERS, L., LYNHAM, J.A., BARTEL, S., KUSCHEL, M., KARCZEWSKI, P. \& KRAUSE, E.-G. (1996). $\beta_{2^{-}}$ Adrenoceptor activation by zinterol causes protein phosphorylation, contractile effects and relaxant effects through a cAMP pathway in human atrium. Mol. Cell. Biochem., 163/164, $113-$ 123.
KOSS, K.L. \& KRANIAS, E.G. (1996). Phospholamban: a prominent regulator of myocardial contractility. Circ. Res., 79, 1059-1063

KOSS, K.L., PONNIAH, S., JONES, W.K., GRUPP, I.L. \& KRANIAS, E.G. (1995). Differential phospholamban gene expression in murine cardiac compartments. Molecular and physiological analyses. Circ. Res., 77, 342-353.

KUZNETSOV, V., PAK, E., ROBINSON, R.B. \& STEINBERG, S.F. (1995). $\beta_{2}$-Adrenergic receptor actions in neonatal and adult rat ventricular myocytes. Circ. Res., 76, 40-52.

LEMOINE, H. \& KAUMANN, A.J. (1982). A novel analysis of concentration-dependence of partial agonism. Ring demethylation of bupranolol results in a high affinity partial agonist (K 105) for myocardial and tracheal $\beta$-adrenoceptors. Naunyn-Schmiedeberg's Arch. Pharmacol., 320, 130-144.

LOWE, M., GRACE, A.A. \& KAUMANN, A.J. (1999). Blockade of putative $\beta_{4^{-}}$and $\beta_{1}$-adrenoceptors by carvedilol in ferret myocardium. Naunyn-Schmiedeberg's Arch. Pharmacol., 359, $400-403$.

LOWE, M., GRACE, A.A., VANDENBERG, J.I. \& KAUMANN, A.J (1998). Action potential shortening through the putative $\beta_{4}$ adrenoceptor in ferret ventricle: comparison with $\beta_{1^{-}}$and $\beta_{2-}$ adrenoceptor-mediated effects. Br. J. Pharmacol., 124, $1341-$ 1344

LOWRY, O.H., ROSEBROUGH, N.J., FARR, A.L. \& RANDALL, R.J. (1951). Protein measurement with the folin phenol reagent. $J$. Biol. Chem., 193, 265-275.

MALINOWSKA, B. \& SCHLICKER, E. (1996). Mediation of the positive chronotropic effect of CGP 12177 and cyanopindolol in the pithed rat by atypical $\beta$-adrenoceptors, different from $\beta_{3}$ adrenoceptors. Br. J. Pharmacol., 117, 943-949.

MARANO, M. \& KAUMANN, A.J. (1976). On the statistics of drugreceptor constants for partial agonists. J. Pharmacol. Exp. Ther. 198, $518-525$.

MOLENAAR, P., SARSERO, D. \& KAUMANN, A.J. (1997). Proposal for the interaction of non-conventional partial agonists and catecholamines with the 'putative $\beta_{4}$-adrenoceptor' in mammalian heart. Clin. Exp. Pharmacol. Physiol., 24, 647-656.

MOORMAN, A.F.M., VERMEULEN, J.L.M., KOBAN, M.U., SCHWARTZ, K., LAMERS, W.H. \& BOHELER, K.R. (1995). Patterns of expression of sarcoplasmic reticulum $\mathrm{Ca}^{2+}$-ATPase and phospholamban mRNAs during rat heart development. Circ. Res., 76, 616-625.

NANOFF, C., FREISSMUTH, M. \& SCHÜTZ, W. (1987). The role of a low $\beta_{1}$-adrenoceptor selectivity of $\left[{ }^{3} \mathrm{H}\right]$-CGP $12177 \mathrm{~A}$ for resolving subtype-selectivity of competitive ligands. Naunyn-Schmiedeberg's Arch. Pharmacol., 336, 519-525.

PAK, M.D. \& FISHMAN, P.H. (1996). Anomalous behaviour of CGP 12177A on $\beta_{1}$-adrenergic receptors. J. Recept. Signal Transduct. Res., 16, $1-23$.

ROBERTSON, S.P., JOHNSON, J.D., HOLROYDE, M.J., KRANIAS, E.G., POTTER, J.D. \& SOLARO, R.J. (1982). The effect of troponin I phosphorylation on the $\mathrm{Ca}^{2+}$-binding properties of the $\mathrm{Ca}^{2+}$. regulatory site of bovine cardiac troponin. J. Biol. Chem., 257, $260-263$.

ROHRER, D.K., CHRUSCINSKI, A., SCHAUBLE, E.H., BERNSTEIN, D. \& KOBILKA, B.K. (1999). Cardiovascular and metabolic alterations in mice lacking both $\beta_{1}$ - and $\beta_{2}$-adrenergic receptors. J. Biol. Chem., 274, $16701-16708$.

SARSERO, D., MOLENAAR, P. \& KAUMANN, A.J. (1997). (-)-[ $\left.{ }^{3} \mathrm{H}\right]$ CGP 12177 labels the atypical $\beta$-adrenoceptor ( $\beta \mathrm{AR}$ ) in rat atrium. The Pharmacologist, 39, 39 (Abstract 104).

SARSERO, D., MOLENAAR, P. \& KAUMANN, A.J. (1998). Validity of $(-)-\left[{ }^{3} \mathrm{H}\right]-\mathrm{CGP} 12177 \mathrm{~A}$ as a radioligand for the "putative $\beta_{4}$ adrenoceptor' in rat atrium. Br. J. Pharmacol., 123, $371-380$.

XIAO, R.-P. \& LAKATTA, E.G. (1993). $\beta_{1}$-Adrenoceptor stimulation and $\beta_{2}$-adrenoceptor stimulation differ in their effects on contraction, cytosolic $\mathrm{Ca}^{2+}$, and $\mathrm{Ca}^{2+}$ current in single rat ventricular cells. Circ. Res., 73, 286-300.

XIAO, R.-P., JI, X. \& LAKATTA, E.G. (1995). Functional coupling of the $\beta_{2}$-adrenoceptor to a pertussis toxin-sensitive $G$ protein in cardiac myocytes. Mol. Pharmacol., 47, 322-329.

ZHANG, R., ZHAO, J., MANDVENO, A. \& POTTER, J.D. (1995). Cardiac troponin I phosphorylation increases the rate of cardiac muscle relaxation. Circ. Res., 76, 1028-1035. 